\title{
A functionalized surface modification with vanadium nanoparticles of various valences against implant-associated bloodstream infection
}

This article was published in the following Dove Press journal:

International Journal of Nanomedicine

18 April 2017

Number of times this article has been viewed

\author{
Jiaxing Wangl,* \\ Huaijuan Zhou ${ }^{2, *}$ \\ Geyong Guo' \\ Tao Cheng' \\ Xiaochun Peng' \\ Xin Mao' \\ Jinhua $\mathrm{Li}^{2-4}$ \\ Xianlong Zhang' \\ 'Department of Orthopaedics, \\ Shanghai Jiao Tong University Affiliated \\ Sixth People's Hospital, Shanghai Jiao \\ Tong University, ${ }^{2}$ State Key Laboratory \\ of High Performance Ceramics and \\ Superfine Microstructure, Shanghai \\ Institute of Ceramics, Chinese \\ Academy of Sciences, Shanghai, \\ ${ }^{3}$ Department of Orthopaedics and \\ Traumatology, Li Ka Shing Faculty \\ of Medicine, The University of Hong \\ Kong, Hong Kong, ${ }^{4}$ University of \\ Chinese Academy of Sciences, Beijing, \\ China \\ *These authors contributed equally \\ to this work
}

Correspondence: Xianlong Zhang Department of Orthopaedics, Shanghai jiao Tong University Affiliated Sixth People's Hospital, Shanghai Jiao Tong University, 600 Yishan Road, Tianlin,

Xuhui, Shanghai 200233, China

Tel +862164369183

$\mathrm{Fax}+862164701363$

Email xlzhang_joint@163.com

Jinhua Li

Department of Orthopaedics and Traumatology, Li Ka Shing Faculty of Medicine, The University of Hong Kong, Pokfulam, Hong Kong, China

Tel +85265408435

Fax +85228185210

Email lijh429@hku.hk

\begin{abstract}
Bloodstream infection, especially with implants involved, is an often life-threatening condition with high mortality rates, imposing a heavy burden on patients and medical systems. Herein, we firstly deposited homogeneous vanadium metal, $\mathrm{V}_{2} \mathrm{O}_{3}, \mathrm{VO}_{2}$, and $\mathrm{V}_{2} \mathrm{O}_{5}$ nanofilms on quartz glass by magnetron sputtering. Using these platforms, we further investigated the potential antimicrobial efficiency of these nano- $\mathrm{VO}_{\mathrm{x}}$ films and the interactions of human erythrocytes and bacteria (methicillin-resistant Staphylococcus aureus and Pseudomonas aeruginosa) with our samples in a novel cell-bacteria coculture model. It was demonstrated that these nano- $\mathrm{VO}_{\mathrm{x}}$ precipitated favorable antibacterial activity on both bacteria, especially on $S$. aureus, and this effect increased with higher vanadium valence. A possible mechanism accountable for these results might be elevated levels of vanadium-induced intracellular reactive oxygen species. More importantly, based on hemolysis assays, our nano- $\mathrm{VO}_{\mathrm{x}}$ films were found to be able to kill prokaryotic cells but were not toxic to mammalian cells, holding the potential for the prevention of implant-related hematogenous infections. As far as we know, this is the first report wherein such nano- $\mathrm{VO}_{\mathrm{x}}$ films have assisted human erythrocytes to combat bacteria in a valence-dependent manner. Additionally, vanadium ions were released from these nano- $\mathrm{VO}_{\mathrm{x}}$ films in a sustained manner, and low-valence films possessed better biocompatibility with human fibroblasts. This work may provide new insights for biomedical applications of inorganic vanadium compounds and attract growing attention in this field. From the perspective of surface modification and functionalization, this study holds promise to avail the prophylaxis of bloodstream infections involving implantable biomedical devices.
\end{abstract}

Keywords: surface modification, red blood cell, antibacterial activities, vanadium, nanomaterials

\section{Introduction}

Nowadays, medical implants have become critical devices in modern health care, though they cause major risks of serious bloodstream infections (BSIs), since these inserts act as a portal for the entry of pathogens into the host bloodstream. ${ }^{1-3}$ Currently, an increasing number of implant-related BSIs not only present high mortality and disability rates but also bring heavy financial burden to families and societies, despite the rapid development of antimicrobial agents, adjunctive therapies, and life-support facilities. ${ }^{4,5}$ Gram-positive Staphylococcus aureus is one of the most common pathogens causing BSIs, ${ }^{3,6}$ and methicillin-resistant $S$. aureus (MRSA) is of great danger especially, since it can invalidate the therapeutic use of most $\beta$-lactam antibiotics of first choice against staphylococci. ${ }^{7}$ Also, in many hospitals Pseudomonas aeruginosa has become an epidemic BSI-associated Gram-negative bacteria, leading to significant 
patient mortality and health care costs. ${ }^{8}$ Moreover, early bacterial colonization on the surface of implants and following biofilm formation contribute to the extreme difficulties in curing such BSIs. ${ }^{910}$ Inappropriate antibiotic treatment may exacerbate BSI-associated mortality. ${ }^{11}$ Therefore, compared with the arduous treatment for these refractory BSIs, preventive strategies seem more effective to combat them. In this context, there is a need to develop new antimicrobial agents and strategies to prevent implant BSIs, especially those applicable in the blood microenvironment. As a promising alternative to the current antibiotic-based method, nanomaterial-based antimicrobials provide a new paradigm for conquering antibiotic-resistant pathogens. ${ }^{12-14}$

Among subcellular organelles, the intracellular mitochondrion has been found to be the main target for the accumulation and cytotoxicity of vanadium species in biological systems. ${ }^{15-17}$ On the basis of endosymbiotic theory, a bacterium is the analogue of the mitochondrion of a mammalian cell. ${ }^{18}$ Therefore, vanadium species have the potential to combat bacteria. In fact, previous works together with our recent study have observed the antibacterial activity of vanadium-coordination organic compounds and inorganic vanadium dioxide $\left(\mathrm{VO}_{2}\right){ }^{19-21}$ The vanadium element has six natural oxidation states. Trivalence $(+3)$, tetravalence $(+4)$, and pentavalence $(+5)$ are the most common forms. For inorganic vanadium oxides, the corresponding oxides are $\mathrm{V}_{2} \mathrm{O}_{3}, \mathrm{VO}_{2}$ and $\mathrm{V}_{2} \mathrm{O}_{5}$. The cytotoxicity of vanadium shows dose dependence. ${ }^{22,23}$ Actually, just as Paracelsus stated, "Alle Dinge sind Gift und nichts ist ohne Gift; allein die Dosis macht daß ein Ding kein Gift ist" ("all substances are poisonous; it is only the dose that differentiates between a poison and a remedy"). ${ }^{24}$ No solid basis exists for categorizing vanadium compounds as harmful toxicants when administered at sensible dosage. ${ }^{22}$ Furthermore, vanadium is presumably one of the essential trace elements in the human body, though this has not yet been definitely proven, ${ }^{22}$ and appropriate dosage of vanadium can regulate phosphate metabolism. ${ }^{25}$ Only high doses of vanadium may cause toxic effects on normal cells. ${ }^{26,27}$

Considering the facts that human red blood cells (erythrocytes) have no mitochondria, bacteria resemble mitochondria, and $S$. aureus causes lysis of host cells by secreting $\alpha$-hemolysin monomers and cytolytic peptides, ${ }^{28,29}$ we were inspired to coculture erythrocytes and bacteria (MRSA and $P$. aeruginosa) on vanadium-containing films and investigate the biological response of erythrocytes and bacteria in this novel coculturing system. Our present work aims to explore whether vanadium-containing surface can show erythrocyte-assisting but bacteria-killing functions. For this purpose, we firstly designed $\mathrm{V}$ metal, $\mathrm{V}_{2} \mathrm{O}_{3}, \mathrm{VO}_{2}$, and $\mathrm{V}_{2} \mathrm{O}_{5}$ nanoparticle films on quartz glass substrates by magnetron sputtering, and further explored the antimicrobial activity of these nano- $\mathrm{VO}_{\mathrm{x}}$ films and interactions of human erythrocytes and bacteria with these samples. We hope this work can provide new insight for potential applications of inorganic vanadium-based nanomaterials as surface functional layers in BSI prophylaxis.

\section{Materials and methods}

\section{Sample preparation and characterization}

Homogeneous $\mathrm{V}$ metal, $\mathrm{V}_{2} \mathrm{O}_{3}$, and $\mathrm{VO}_{2}$ films of high quality were prepared by a magnetron-sputtering apparatus (ACS4000-C4; Ulvac Technologies, Methuen, MA, USA) using corresponding vanadium metal and oxide targets. To obtain $\mathrm{V}_{2} \mathrm{O}_{5}$ film, deposited $\mathrm{VO}_{2}$ film underwent subsequent annealing at $450^{\circ} \mathrm{C}$ in $\mathrm{O}_{2}$ atmosphere. The thicknesses of these films were detected by an F20 thin-film analyzer (Filmetrics, San Diego, CA, USA). The samples used all had the same thickness of $50 \mathrm{~nm}$. Fused quartz $\left(\mathrm{SiO}_{2}\right)$ acted as the deposition substrate for films. The whole fabrication process is illustrated in Scheme 1. The samples were denoted as glass (quartz), V0 (homogeneous vanadium metal nanoparticles deposited on quartz glass), $\mathrm{V} 3$ (homogeneous $\mathrm{V}_{2} \mathrm{O}_{3}$ nanoparticles deposited on quartz glass), $\mathrm{V} 4$ (homogeneous $\mathrm{VO}_{2}$ nanoparticles deposited on quartz glass), and V5 (homogeneous $\mathrm{V}_{2} \mathrm{O}_{5}$ nanoparticles deposited on quartz glass).

Field-emission scanning electron microscopy (SEM; S-4800; Hitachi, Tokyo, Japan) was used to observe the surface morphology of the samples. X-ray diffraction (XRD; Ultima IV; Rigaku, Tokyo, Japan) was utilized to study the crystalline structure of films, fitted with $\mathrm{CuK} \alpha$ radiation $(\lambda=1.541 \AA)$ at voltage of $40 \mathrm{kV}$ and current of $40 \mathrm{~mA}$. The $\mathrm{XRD}$ patterns were recorded in the range of $15^{\circ}-80^{\circ}(2 \theta)$ with step size of $0.02^{\circ}$ and scanning rate of $2^{\circ} / \mathrm{min}$. For the $\mathrm{XRD}$ test, the glancing-incidence angle was fixed at $1^{\circ}$. Phase identification was performed with the help of the standard Joint Committee on Powder Diffraction Standards database. The chemical composition, chemical state, and elemental depth profile were studied by X-ray photoelectron spectroscopy (XPS; Escalab 250Xi; Thermo Fisher Scientific, Waltham, MA, USA) with $\mathrm{Al}_{\mathrm{K} \alpha}(1,486.6 \mathrm{eV})$ illumination.

\section{Vanadium-ion release}

The release profiles of vanadium ions from the V0, V3, V4 and V5 samples immersed in Dulbecco's Modified Eagle's Medium (DMEM), trypticase soy broth (TSB), 


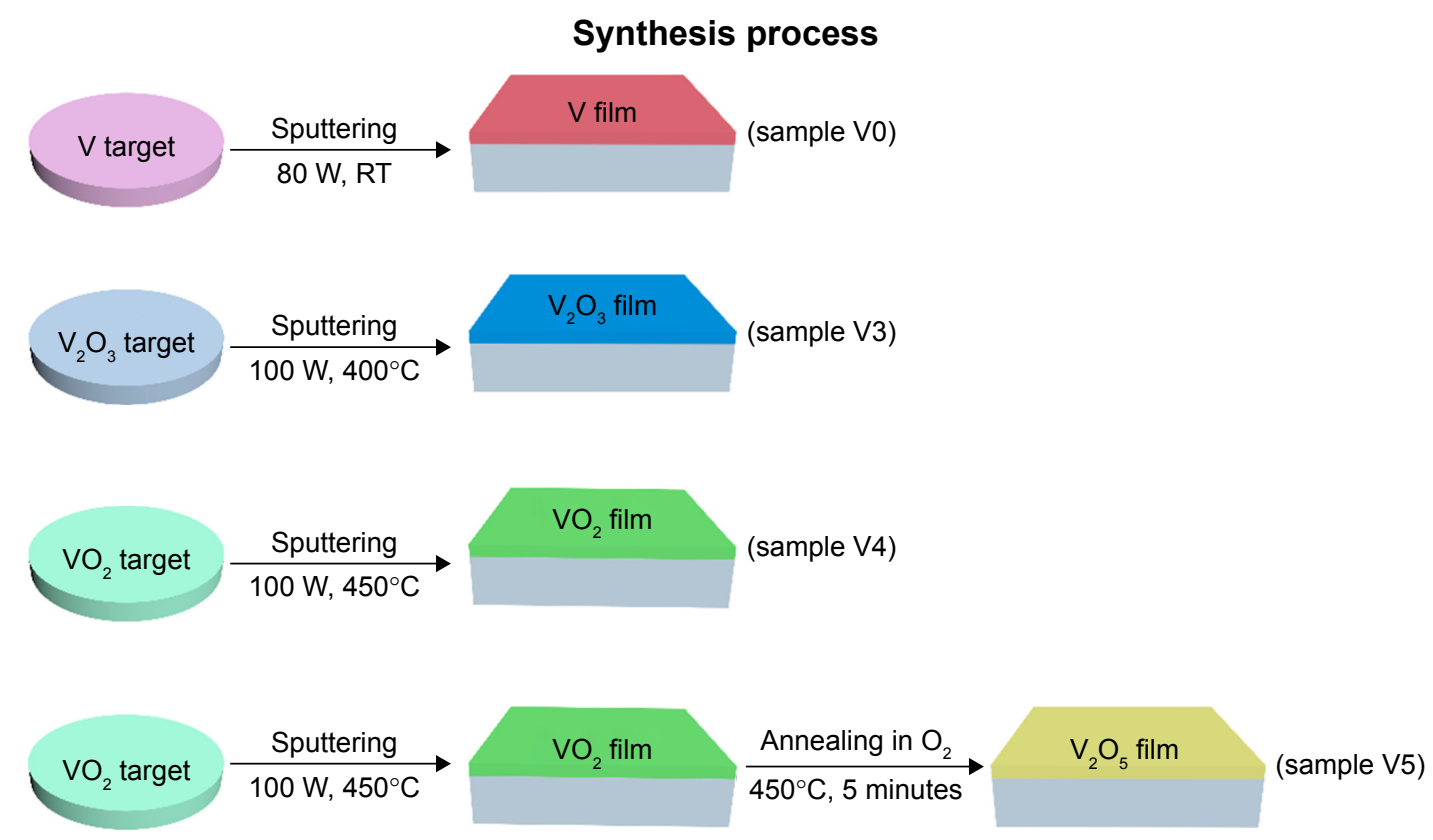

Scheme I Illustration of the fabrication process of samples V0, V3, V4, and V5 by magnetron sputtering.

Abbreviations: RT, room temperature; $\mathrm{V} 0$, homogeneous vanadium metal nanoparticles deposited on quartz glass; $\mathrm{V} 3$, homogeneous $\mathrm{V}_{2} \mathrm{O}_{3}$ nanoparticles deposited on quartz glass; $\mathrm{V} 4$, homogeneous $\mathrm{VO}_{2}$ nanoparticles deposited on quartz glass; $\mathrm{V} 5$, homogeneous $\mathrm{V}_{2} \mathrm{O}_{5}$ nanoparticles deposited on quartz glass.

and phosphate-buffered saline (PBS) were detected by inductively coupled plasma optical emission spectrometry (Liberty 150; Varian Medical Systems, Palo Alto, CA, USA). The testing samples were positioned in sterile microcentrifuge tubes $(15 \mathrm{~mL})$ filled with $10 \mathrm{~mL}$ fresh medium, followed by 1, 4, 7 and 14 days of sequential incubation at $37^{\circ} \mathrm{C}$ in static conditions. At the end of each incubation period, all the leachates were collected for detection and the microcentrifuge tubes supplemented with fresh medium for subsequent incubation.

\section{In vitro cytotoxicity evaluation}

The human HFF1 cell line was utilized to assess the cytotoxicity of our specimens, and cell viability was determined with the CCK-8 assay (Beyotime, Haimen, China). The glass, $\mathrm{V} 0, \mathrm{~V} 3, \mathrm{~V} 4$, and V5 samples were sterilized in ethanol solution $(75 \mathrm{v} / \mathrm{v} \%)$ and dried on a clean bench. HFF1 cells were kindly provided by the Stem Cell Bank, Chinese Academy of Sciences (Beijing, China). The cell-growth medium consisted of DMEM and 10\% fetal bovine serum (both Thermo Fisher Scientific). The five samples were first placed on a 24-well plate, and then $1 \mathrm{~mL}$ cell suspensions with a density of $5 \times 10^{4} / \mathrm{mL}$ were added. They were statically cultured for 1 day at $37^{\circ} \mathrm{C}$ in a humidified atmosphere filled with $5 \%$ $\mathrm{CO}_{2}$. The next day, we removed the stale culture medium and added $1 \mathrm{~mL}$ fresh medium, including $10 \% \mathrm{CCK}-8$, into each well for incubation of 2 hours. Lastly, we transferred
$100 \mu \mathrm{L}$ of the medium from the 24 -well plate to a new $96-$ well plate, and absorbance was detected by a microplate reader at $450 \mathrm{~nm}$ wavelength.

\section{Qualitative assessment of adherent HFFI cells by fluorescence microscopy}

To evaluate cell morphology and adhesion and spreading behaviors, the HFF1 cells were seeded on various samples at a density of $5 \times 10^{4}$ cells $/ \mathrm{mL}$, incubated for 24 hours at $37^{\circ} \mathrm{C}$, and then gently washed twice with fresh PBS, fixed with $4 \%$ formaldehyde for 30 minutes, permeabilized with PBS containing $0.1 \%$ Triton X-100, and finally stained with tetraethyl rhodamine isothiocyanate-phalloidin and 4',6-diamidino-2-phenylindole. Cell nuclei and cytoskeletal actin were observed by fluorescence microscopy (Leica Microsystems, Wetzlar, Germany).

\section{In vitro antibacterial assay}

Gram-positive MRSA (biofilm-positive; American Type Culture Collection 43300) and Gram-negative P. aeruginosa (biofilm-positive; American Type Culture Collection 27853) were used to determine the antibacterial property of the glass, V0, V3, V4, and V5 samples. The two representative strains were first cultured in fresh TSB at $37^{\circ} \mathrm{C}$ overnight, and then (based on McFarland standards) their inoculation concentrations were both adjusted to $10^{6} \mathrm{CFU} / \mathrm{mL}$ in TSB . Each specimen was placed into a sterile 24-well plate, and 
$500 \mu \mathrm{L}$ of prepared bacterial suspension was added to the wells. The 24-well plate was then kept in an incubator statically at $37^{\circ} \mathrm{C}$ for 18 hours. At the end, we dealt with the original medium with planktonic bacteria through serial dilution, and viable swimming bacteria were counted by the spread-plate method (SPM). In addition, we used sterile tweezers to take out the samples from the suspension and gently dislodged the nonadherent bacteria with fresh PBS twice. Then, each sample was put in a sterile test tube that included $1 \mathrm{~mL}$ fresh PBS and oscillated by ultrasonic vibration for 15 minutes (150 W; B3500S-MT; Emerson, St Louis, MO, USA) and vortex mixing (Vortex Genie 2; Scientific Industries, Bohemia, NY, USA) for 1 minute. A bacterial suspension with adhered bacteria was acquired and viable bacteria enumerated by the SPM. In line with the National Standard of China GB/T 4789.2 protocol, CFU amounts on sheep-blood agar (SBA) were enumerated.

Antimicrobial rates for planktonic and sessile bacteria were computed on the basis of the following formulae:

Planktonic bacteria in TSB medium $($ Rap \%) =

$$
\frac{a-b}{a} \times 100 \%
$$

Sessile bacteria on the specimen $(\operatorname{Raa} \%)=$

$$
\frac{c-d}{c} \times 100 \%
$$

where $b$ is the average number of living bacteria in TSB medium with glass, V0, V3, V4, or V5, $a$ mean viable cells in TSB inoculated with glass, $d$ average number of living bacteria on the surface of glass, V0, V3, V4, or V5, and $c$ mean viable cells on the surface of glass.

\section{Qualitative evaluation of planktonic bacteria by improved SPM}

The antibacterial efficiency of our samples against planktonic bacteria was also qualitatively assessed by improved SPM, ie, $100 \mu \mathrm{L}$ of diluent bacterial suspension was evenly spread on the fresh SBA and cultivated overnight at $37^{\circ} \mathrm{C}$. Representative photos were obtained.

\section{Qualitative assessment of adherent bacteria by SEM}

Incubated specimens were gently washed with fresh PBS three times to remove nonadherent bacteria, fixed with $2.5 \%$ glutaraldehyde overnight at $4^{\circ} \mathrm{C}$ in a freezer, and subsequently dehydrated in the ethanol series 30, 50, 70, 80, 90, and $95 \mathrm{v} / \mathrm{v} \%$ for 10 minutes and in absolute ethanol solution (twice for 10 minutes). Then, our samples were treated with desiccation and sprayed gold, and finally examined by SEM (JSM-6310LV; JEOL, Tokyo, Japan).

\section{Qualitative assessment of adherent bacteria by CLSM}

Surfaces of incubated specimens were gently washed with sterile PBS three times to dislodge nonadherent bacteria. Then, these samples were placed into a new 24-well plate, stained with $500 \mu \mathrm{L}$ of mixed dye (BacLight live/dead bacteria-viability kit; Thermo Fisher Scientific) in the dark for 20 minutes. Lastly, the samples were lightly rinsed with fresh PBS and subsequently observed by confocal laserscanning microscopy (CLSM; 510 Meta; Carl Zeiss Meditec AG, Jena, Germany). Cells stained with green fluorescent dye represented viable bacteria, and those with red fluorescent dye were dead bacteria.

\section{Intracellular reactive oxygen species assay}

Oxidative stress levels in bacteria upon exposure to nanoparticle films were estimated by an intracellular reactive oxygen species (ROS) assay kit (Beyotime) using 2', $7^{\prime}$ dichlorodihydrofluorescein diacetate (DCFH-DA) as a fluorescent probe. ${ }^{30}$ All procedures followed the manufacturer's instructions strictly. In brief, after overnight culture, the bacteria were gently rinsed with PBS twice. Then, the DCFH-DA was diluted into a final concentration of $10 \mu \mathrm{M}$ staining solution using PBS. Subsequently, the DCFH-DA staining solution was added to each well sample, followed by 20 minutes of incubation at $37^{\circ} \mathrm{C}$, and then observed immediately on CLSM at excitation/emission wavelengths of 488/535 nm. Laser-beam intensity and photodetector sensitivity were kept constant to compare the relative fluorescence intensities among various groups.

\section{Antioxidant-incubation study}

We intended to investigate whether oxidative stress plays a role in bacterial response to the present nanoparticle films. Therefore, according to a previous strategy, ${ }^{20}$ we coincubated $S$. aureus and $P$. aeruginosa in TSB with $10 \mathrm{mM}$ glutathione (GSH; reduced form), the primary endogenous antioxidant, to neutralize the function of oxidative stress when bacteria were exposed to our nanosamples. The bacterial viability of swimming and adhered cells was quantitatively assessed through using the aforementioned methods. Moreover, SEM and CLSM were also used to observe the morphology and viability of adherent bacteria in TSB and GSH media. 


\section{Hemolysis assays}

Hemolysis assays were completed based on previous literature. ${ }^{20}$ Our experiments were approved by the ethics review committee of Shanghai Jiao Tong University Sixth People's Hospital. Volunteers whose blood was used provided informed consent to donate the blood. Red blood cells (RBCs) were isolated from the venous blood of healthy young volunteers, washed with sterile PBS three times, and finally resuspended in PBS at 2\% hematocrit. In order to examine the effect of $\mathrm{VO}_{\mathrm{x}}$ nanoparticle films on erythrocyte lysis, RBCs were incubated with or without bacteria (S. aureus and P. aeruginosa), followed by treatment with various samples for 24 hours at $37^{\circ} \mathrm{C}$. The final concentration of bacterial suspension in the bacteria-biomaterial coculture system was $10^{6} \mathrm{CFU} / \mathrm{mL}$. Aseptic distilled water was used as a positive control. At the end of incubation, one aliquot of reaction mixture was withdrawn and centrifuged at $1,200 \mathrm{~g}$ for 5 minutes. Supernatants were acquired and hemolysis determined by measuring their absorbance at $540 \mathrm{~nm}$. The percentage of hemolysis was calculated thus:

$$
\text { Hemolysis rate }=\frac{A}{B} \times 100 \%
$$

where $A$ was the absorbance of our samples and $B$ the absorbance of the positive control.

\section{Statistical analysis}

Statistically significant differences between various groups were measured using one-way analysis of variance and Tukey's multiple-comparison tests on GraphPad Prism 5 statistical software. All data are expressed as means \pm standard deviation. Values of $P<0.05$ were considered statistically significant.

\section{Results and discussion Sample characterization}

Figure 1 shows the surface morphologies of various samples. At room-temperature sputtering using the V-metal target, homogeneous nanoparticle film appeared on the substrate surface (Figure 1A). Similarly, using the $\mathrm{V}_{2} \mathrm{O}_{3}$ target, a uniform film of nanoparticle topography emerged on the surface after magnetron sputtering (Figure 1B). This was also the same for $\mathrm{VO}_{2}$-target sputtering, as seen in Figure 1C. For $\mathrm{V}_{2} \mathrm{O}_{5}$ preparation, predeposited $\mathrm{VO}_{2}$ film underwent subsequent annealing and produced the observed surfacenanoparticle topography in Figure 1D, indicating the development of nanoparticles due to phase evolution.

Figure 2A gives the XRD patterns of various samples. For quartz glass (substrate), only an amorphous peak was detected. For sample V0, the diffraction peak of the (111) plane was detected for the V-metal phase. For sample V3, the diffraction peaks of the (110), (113), and (116) planes were
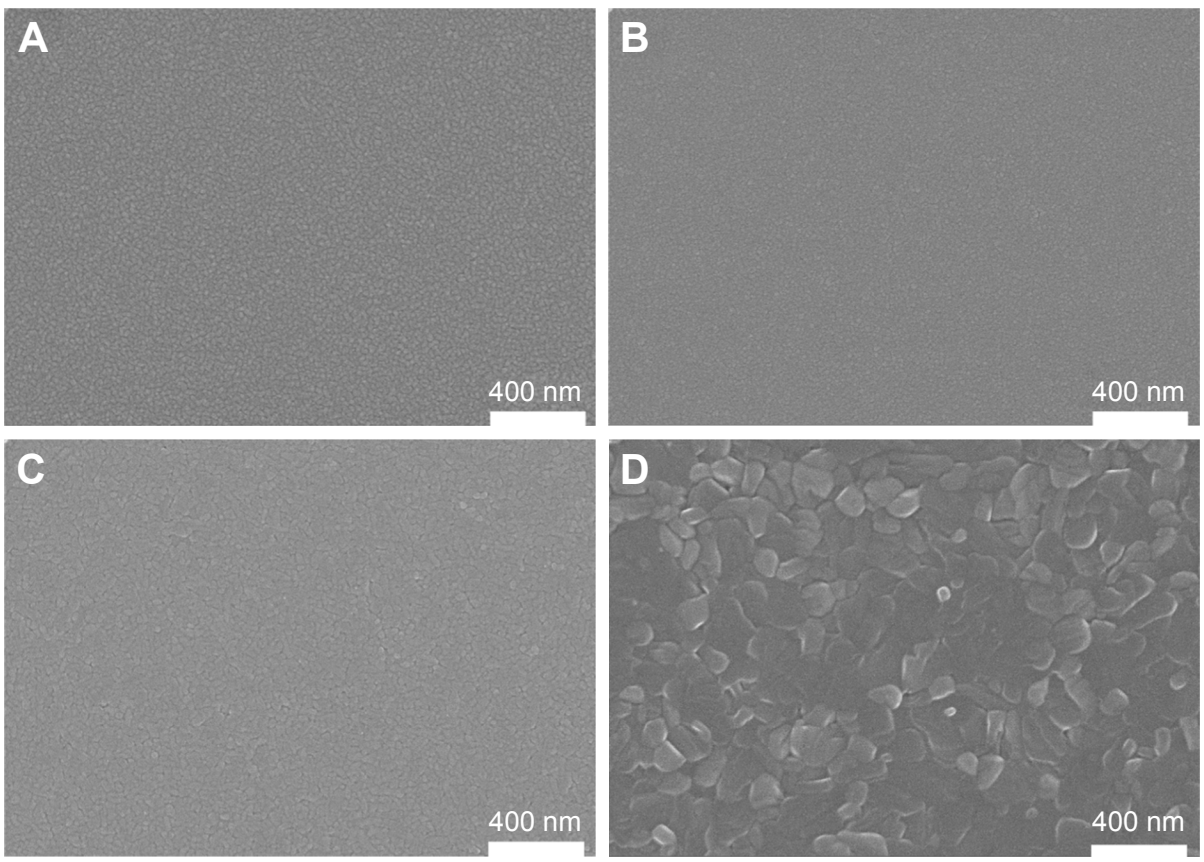

Figure I SEM morphology of various surfaces of samples V0 (A), V3 (B), V4 (C), and V5 (D).

Abbreviations: SEM, scanning electron microscopy; $V 0$, homogeneous vanadium metal nanoparticles deposited on quartz glass; $V_{3}$, homogeneous $\mathrm{V}_{2} \mathrm{O}_{3}$ nanoparticles deposited on quartz glass; $\mathrm{V} 4$, homogeneous $\mathrm{VO}_{2}$ nanoparticles deposited on quartz glass; $\mathrm{V} 5$, homogeneous $\mathrm{V}_{2} \mathrm{O}_{5}$ nanoparticles deposited on quartz glass. 

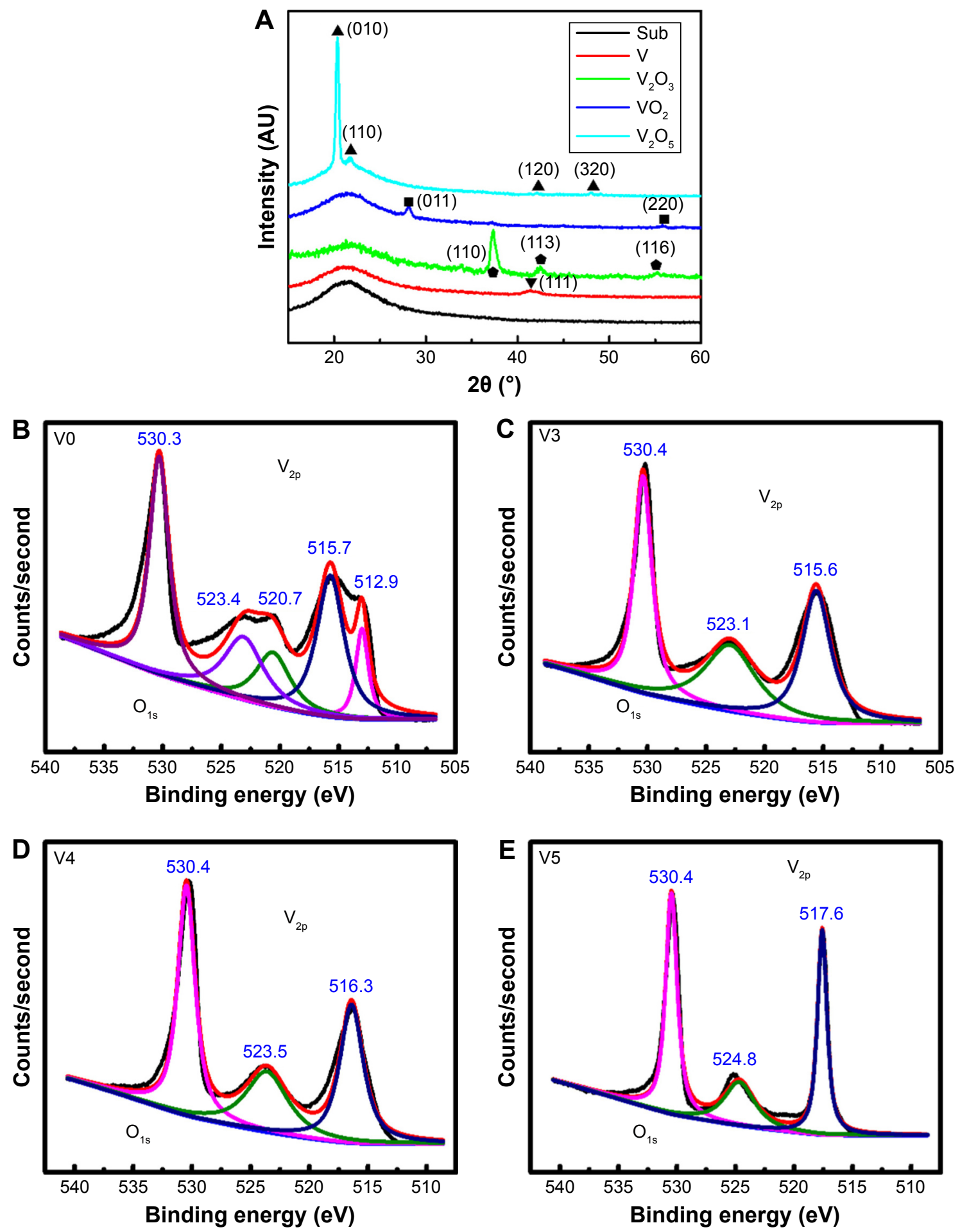

Figure 2 XRD patterns (A) of samples V0, V3, V4, and V5, accompanied by the $\mathrm{V}_{2 \mathrm{p}}$ XPS spectra of samples V0 (B), V3 (C), V4 (D), and V5 (E).

Abbreviations: XRD, X-ray diffraction; XPS, X-ray photoelectron spectroscopy; V0, homogeneous vanadium metal nanoparticles deposited on quartz glass; $\mathrm{V} 3$, homogeneous $\mathrm{V}_{2} \mathrm{O}_{3}$ nanoparticles deposited on quartz glass; $\mathrm{V} 4$, homogeneous $\mathrm{VO}_{2}$ nanoparticles deposited on quartz glass; $V 5$, homogeneous $\mathrm{V}_{2} \mathrm{O}_{5}$ nanoparticles deposited on quartz glass.

determined for the $\mathrm{V}_{2} \mathrm{O}_{3}$ phase. For sample V4, the peaks of the (011) and (220) planes were observed for the $\mathrm{VO}_{2}$ phase. As for sample V5, the characteristic peaks of the (010), (110), (120), and (320) planes were detected for the $\mathrm{V}_{2} \mathrm{O}_{5}$ phase. Figure 2B-E shows the $\mathrm{V}_{2 \mathrm{p}}-\mathrm{O}_{1 \mathrm{~s}}$ XPS spectra acquired from various surfaces. A binding energy of around $530.4 \mathrm{eV}$ was found for the $\mathrm{O}_{1 \mathrm{~s}}$ peak in vanadium oxides. For sample V0, as seen in Figure 2B, two doublet peaks appeared for $\mathrm{V}_{2 \mathrm{p}}$. Doublet peaks at $512.9 \mathrm{eV}$ and $520.7 \mathrm{eV}$ corresponded to $\mathrm{V}_{2 \mathrm{p} 3 / 2}$ and $\mathrm{V}_{2 \mathrm{p} 1 / 2}$ in $\mathrm{V}$ metal. ${ }^{31}$ Other doublet peaks at $515.7 \mathrm{eV}$ 
and $523.4 \mathrm{eV}$ belonged to $\mathrm{V}_{2 \mathrm{p} 3 / 2}$ and $\mathrm{V}_{2 \mathrm{p} 1 / 2}$ in $\mathrm{V}_{2} \mathrm{O}_{3}$, 32 indicating the partial natural oxidation of the $\mathrm{V}$-metal nanoparticle surface $\left(4 \mathrm{~V}+3 \mathrm{O}_{2} \rightarrow 2 \mathrm{~V}_{2} \mathrm{O}_{3}\right)$. As for sample $\mathrm{V} 3$ (Figure $2 \mathrm{C}$ ), doublet peaks at $515.6 \mathrm{eV}$ and $523.1 \mathrm{eV}$ belonged to $\mathrm{V}_{2 \mathrm{p} 3 / 2}$ and $\mathrm{V}_{2 \mathrm{p} 1 / 2}$ in $\mathrm{V}_{2} \mathrm{O}_{3}$. With regard to sample $\mathrm{V} 4$ (Figure 2D), doublet peaks at $516.3 \mathrm{eV}$ and $523.5 \mathrm{eV}$ were assigned to $\mathrm{V}_{2 \mathrm{p} 3 / 2}$ and $\mathrm{V}_{2 \mathrm{p} 1 / 2}$ in $\mathrm{VO}_{2} \cdot{ }^{33}$ With regard to sample $\mathrm{V} 5$, as shown in Figure 2E, doublet peaks at $517.6 \mathrm{eV}$ and $524.8 \mathrm{eV}$ belonged to $\mathrm{V}_{2 \mathrm{p} 3 / 2}$ and $\mathrm{V}_{2 \mathrm{p} 1 / 2}$ in $\mathrm{V}_{2} \mathrm{O}_{5} \cdot{ }^{34}$ Overall, the XPS and $\mathrm{XRD}$ data were quite consistent.

\section{Vanadium-ion release}

Figure 3 shows the release profiles of vanadium ions in DMEM, TSB, and PBS media after immersion for 1, 4, 7, and 14 days. With DMEM (Figure 3A), vanadium ions were continuously released from various samples, especially for sample V0. This was also true for vanadium release from samples V3, V4, and V5 in TSB (Figure 3B) and PBS (Figure 3C).

\section{Biocompatibility}

Normally, indwelling medical devices holding promise for future clinical transformation should possess good biocompatibility. At first, we used human HFF1 fibroblasts to evaluate the biocompatibility of glass, V0, V3, V4, and V5 samples. As seen in Figure 4, after 1 day of culture on various samples, cell viability in V0/V3/V4 and glass showed no significant difference, while V5 produced an obvious difference compared with glass. V3/V4/V5 also showed significant differences in comparison to $\mathrm{V} 0$. Vanadium has six chemical valence states, and vanadium cytotoxicity ascends with valence states. ${ }^{23}$ This may account

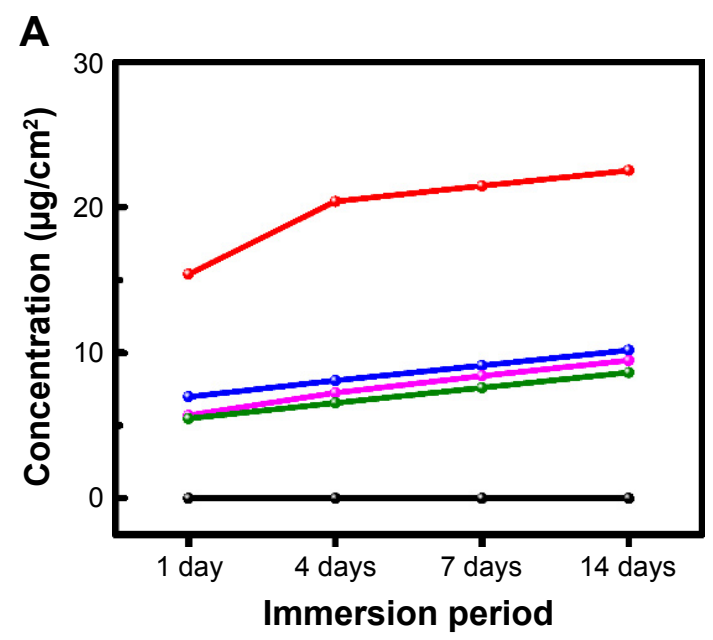

B

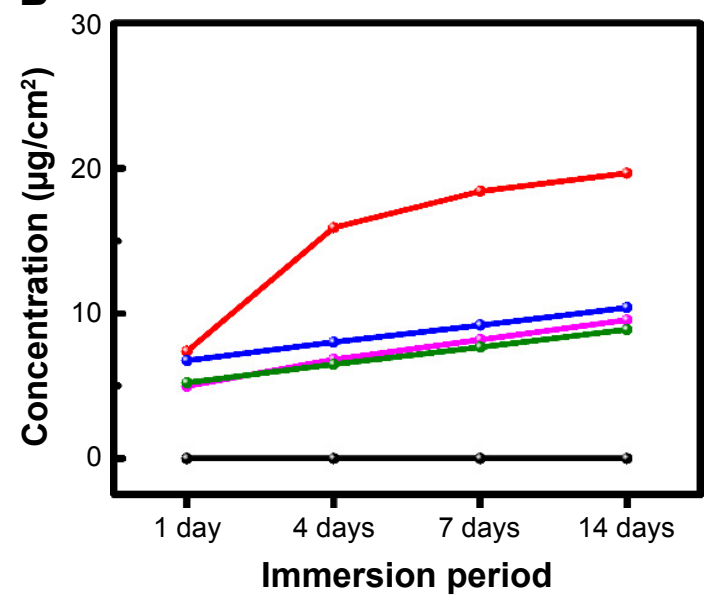

C

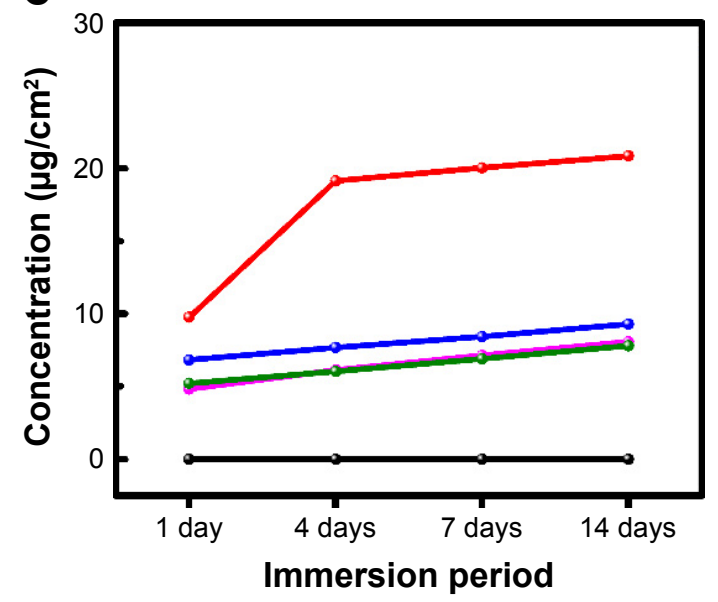

$\longrightarrow$ Glass $\longrightarrow$ V0 $\nrightarrow$ V3 $\multimap$ V4

Figure 3 Release profiles of vanadium ions from various samples after soaking in DMEM (A), TSB (B), and PBS (C).

Abbreviations: DMEM, Dulbecco's Modified Eagle's Medium; TSB, trypticase soy broth; PBS, phosphate-buffered saline; V0, homogeneous vanadium metal nanoparticles deposited on quartz glass; $\mathrm{V} 3$, homogeneous $\mathrm{V}_{2} \mathrm{O}_{3}$ nanoparticles deposited on quartz glass; $\mathrm{V} 4$, homogeneous $\mathrm{VO}_{2}$ nanoparticles deposited on quartz glass; $\mathrm{V} 5$, homogeneous $\mathrm{V}_{2} \mathrm{O}_{5}$ nanoparticles deposited on quartz glass. 

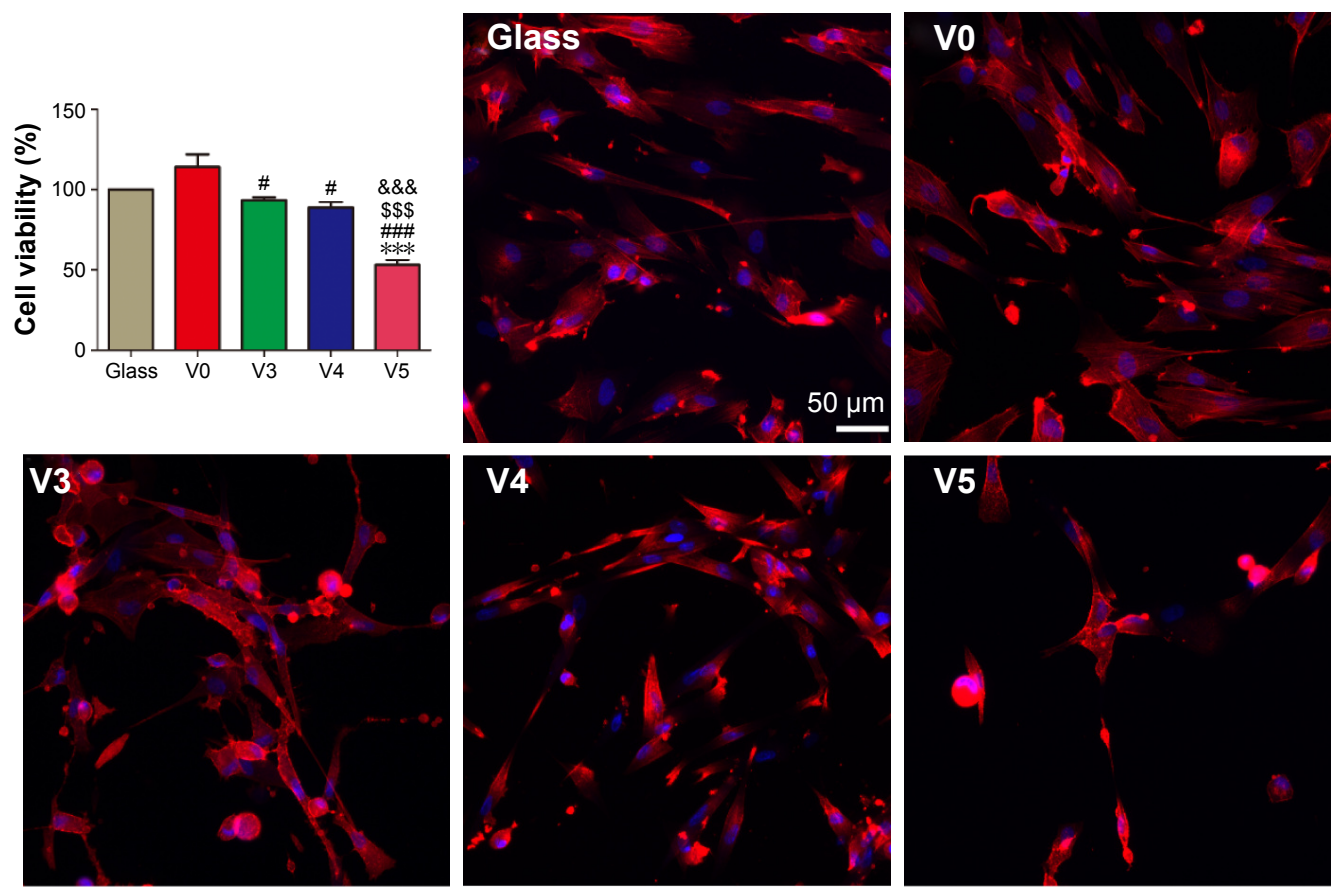

Figure 4 Proliferation viability of HFFI cells after 24-hour culture on the glass, V0, V3, V4, and V5 samples.

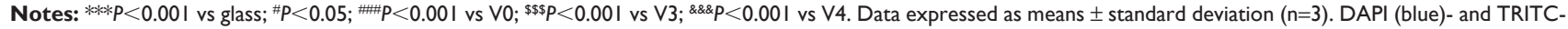
phalloidin (red)-stained fluorescent images of HFFI cells on the five specimens after I-day culture.

Abbreviations: V0, homogeneous vanadium metal nanoparticles deposited on quartz glass; $\mathrm{V} 3$, homogeneous $\mathrm{V}_{2} \mathrm{O}_{3}$ nanoparticles deposited on quartz glass; $\mathrm{V} 4$, homogeneous $\mathrm{VO}_{2}$ nanoparticles deposited on quartz glass; $\mathrm{V} 5$, homogeneous $\mathrm{V}_{2} \mathrm{O}_{5}$ nanoparticles deposited on quartz glass; DAPI, 4',6-diamidino-2-phenylindole; TRITC, tetraethyl rhodamine isothiocyanate.

for V3/V4/V5 with relatively low vanadium-release amounts producing more toxic effects on HFF1 compared with V0 with relatively high vanadium-release amounts. Furthermore, as seen in Figure 4, cell adhesion and the cytoskeleton were also fluorescently stained to visualize the HFF1 state. In detail, the HFF1 cells adhered and spread well on glass and V0 surfaces. This was also similar for samples V3 and V4. By contrast, the adhesion and spreading of HFF1 cells on V5 were obviously inhibited. Overall, this revealed a valencestate-dependent trend.

\section{Antibacterial activity}

To investigate the antimicrobial behavior and mechanism of the vanadium-nanoparticle films, we adopted a comparative study method of using GSH antioxidant to evaluate antibacterial ability, with reference to in vitro antibacterial tests in previous studies, ${ }^{20,35}$ which usually focused on exploring the effects that the materials exerted on planktonic and sessile bacteria. After 24 hours of culture on glass, V0, V3, V4, and V5 with/without GSH coincubation, the planktonic bacteria (MRSA and P. aeruginosa) were firstly collected and recultivated on SBA overnight. Representative images are given in Figure 5. Combined with the corresponding counting results in Figure 6, it can be seen that for Gram-positive MRSA, the V,
$\mathrm{V}_{2} \mathrm{O}_{3}, \mathrm{VO}_{2}$, and $\mathrm{V}_{2} \mathrm{O}_{5}$ films exhibited significant antibacterial activity toward MRSA in the order of V0, V3, V4, and V5, with obvious differences among groups, showing the close correlation with the valence states of vanadium (Figure 6A). Interestingly, for Gram-negative $P$. aeruginosa, the trend was not completely the same. As seen in Figure 6B, V0 showed good antibacterial ability against $P$. aeruginosa, and this may have resulted from the natural oxidation of $\mathrm{V}$ metal upon air exposure to form the $\mathrm{V}_{2} \mathrm{O}_{3}$ phase on the outermost surface. Sample V3 presented stronger antibacterial activity than V0. However, sample V4 did not exhibit antibacterial properties, which was consistent with our recent work. ${ }^{20}$ Compared with V0 and V3, sample V5 revealed more effective antibacterial capacity on $P$. aeruginosa. As a result, the antiplanktonic bacterial ability of the various samples had a relationship with the vanadium-oxidation states, and this is further discussed in the next section.

Furthermore, from oxidation and reduction chemistry, we tried to explore the role of vanadium-valence states in oxidative stress induction using GSH coincubation. As seen in Figure 5, after coincubation with GSH antioxidant, no visible difference in planktonic bacteria-colony formation was observed among groups. Combined with the corresponding quantitative data in Figure $6 \mathrm{C}$ and D, there 
A

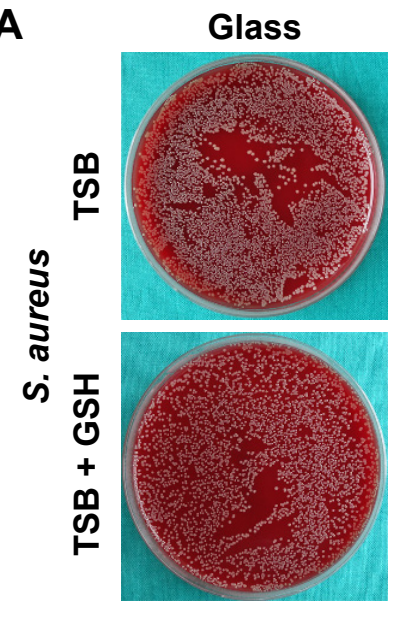

B

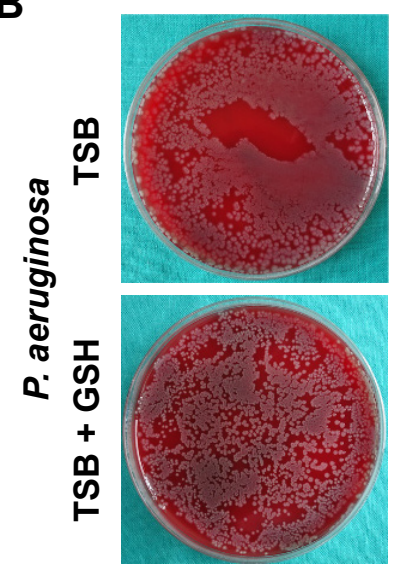

vo
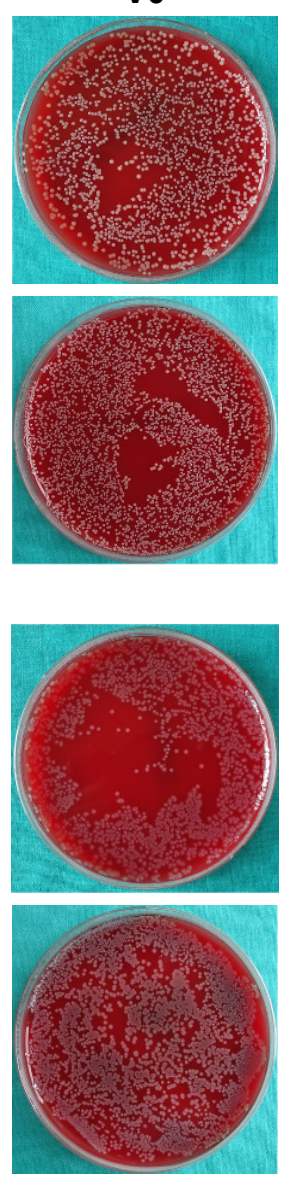

V3
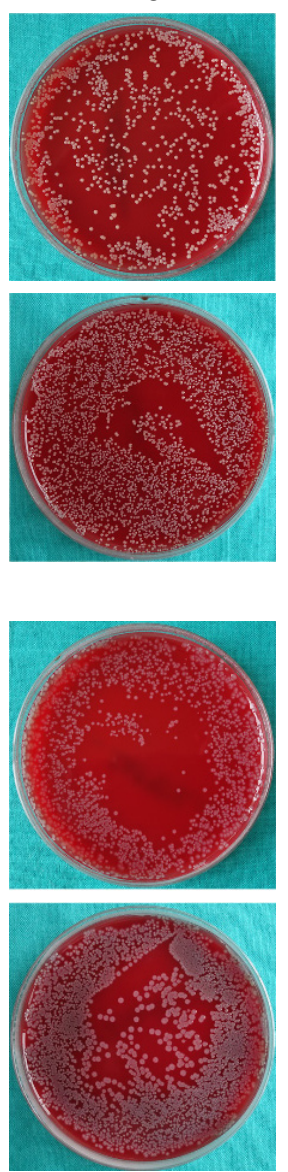

V4
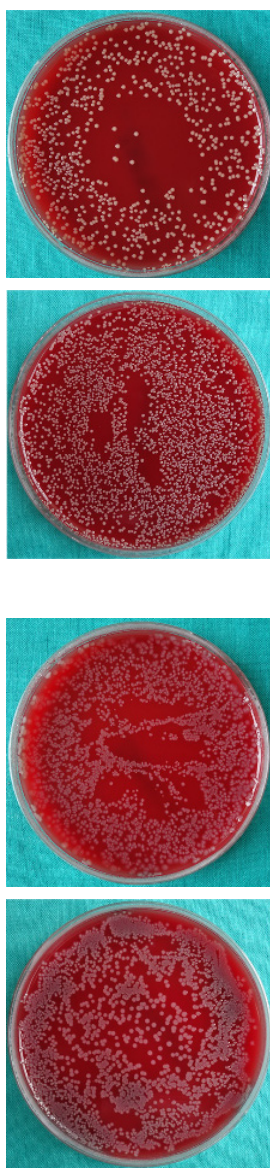

V5
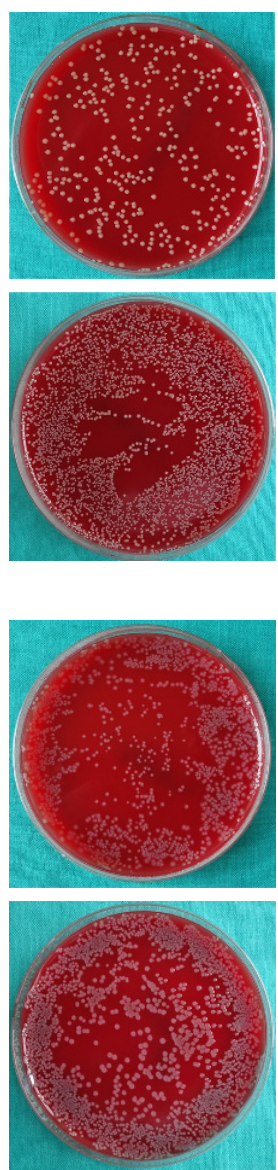

Figure 5 Qualitative assessment of antiseptic capacity against two types of planktonic bacteria.

Notes: (A) For Staphylococcus aureus, representative pictures of recultivated bacteria colonies on SBA for five samples in the TSB or TSB + GSH culture medium; (B) for Pseudomonas aeruginosa, representative pictures of recultivated bacteria colonies on SBA for five samples in the TSB or TSB + GSH culture medium.

Abbreviations: SBA, sheep-blood agar; TSB, trypticase soy broth; $V 0$, homogeneous vanadium metal nanoparticles deposited on quartz glass; $V 3$, homogeneous $\mathrm{V}_{2} \mathrm{O}_{3}$ nanoparticles deposited on quartz glass; $\mathrm{V} 4$, homogeneous $\mathrm{VO}_{2}$ nanoparticles deposited on quartz glass; $\mathrm{V} 5$, homogeneous $\mathrm{V}_{2} \mathrm{O}_{5}$ nanoparticles deposited on quartz glass.

were no significant differences among the bacteria-counting results of various groups, indicating that GSH eliminated the antibacterial capability of V0, V3, V4 and V5 against planktonic MRSA or $P$. aeruginosa. This sharp contrast further implied that these samples should exert antibacterial activity by inducing oxidative stress and oxidative damage. In addition, overall, the V0, V3, and V5 samples possessed relatively stronger antibacterial activity on MRSA than on P. aeruginosa. This can be attributed to the higher tolerance of $P$. aeruginosa toward oxidative stress. ${ }^{20}$ It should also be noted that antibacterial efficiency of around $20 \%$ is actually low for combating bacteria.

Likewise, we detached the adherent bacteria (MRSA and $P$. aeruginosa) from sample surfaces and then recultivated them on the SBA overnight. The counting results of bacteria colonies are given in Figure 7. As seen in Figure 7A and $\mathrm{B}$, the antiadherent bacterial activity of various samples showed a similar trend to the antiplanktonic bacterial ability seen in Figure 6A and B. Similarly, coincubation with GSH antioxidant also removed the antiadherent bacterial ability of the various samples, as evidenced in Figure 7C and D. This further confirmed that these samples also imposed antiadherent bacterial ability by triggering oxidative stress and oxidative damage.

As a kind of visual qualitative evaluation method, SEM was also performed to investigate the adherent bacteria state and morphology. The results are shown in Figure 8. As seen in Figure 8A, counts of adherent MRSA were regularly reduced on various samples in the order of V0, V3, V4, and V5 compared with glass, especially for samples V3, V4, and V5, whereas after GSH coincubation, all samples promoted bacterial adhesion and proliferation on the surface, showing no obvious differences among groups. This was accordant with the aforementioned quantitative results (Figure 7A and C). Likewise, for adherent $P$. aeruginosa, the SEM results in Figure $8 \mathrm{~B}$ also agreed well with bacteria-counting results 

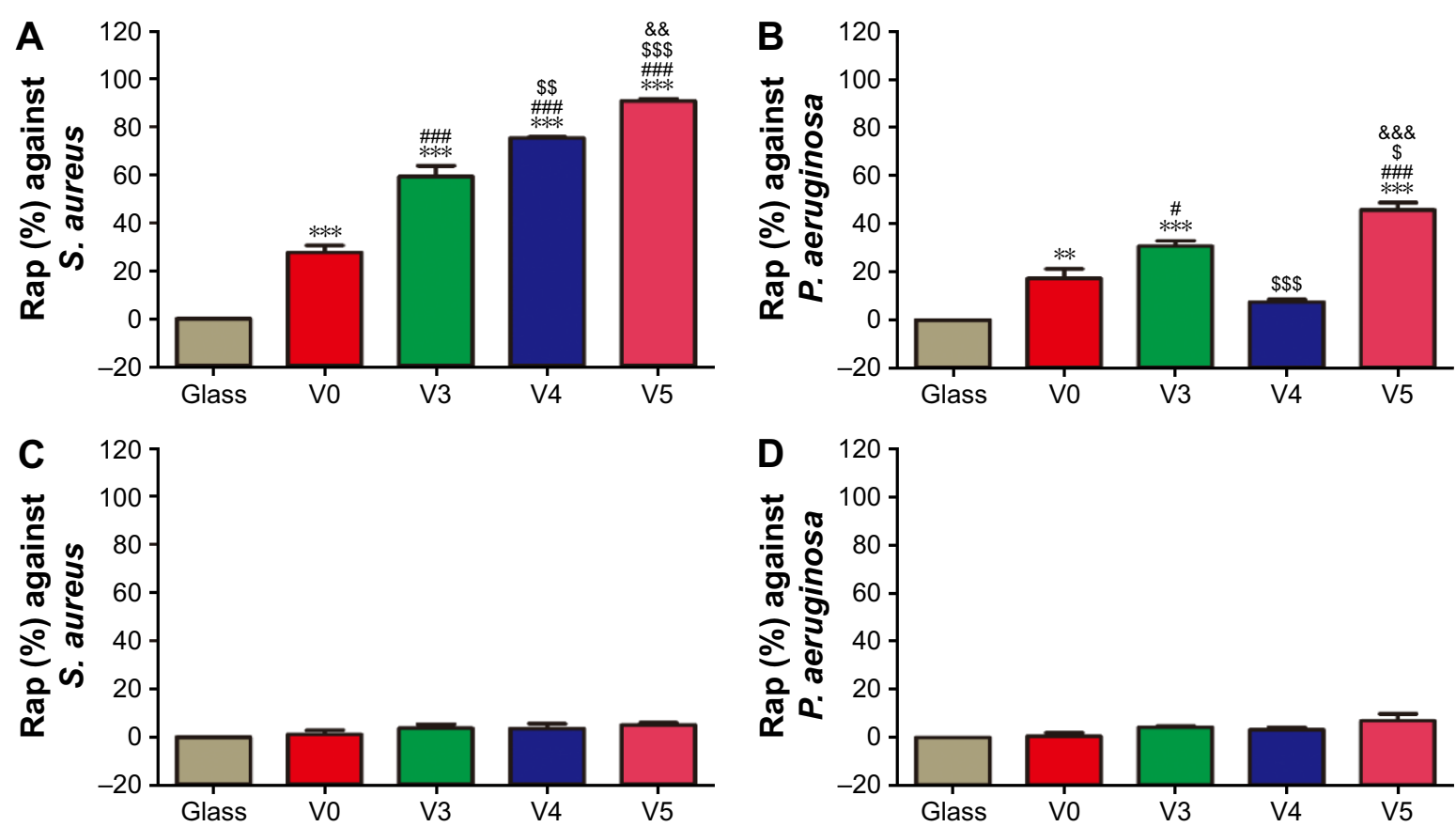

Figure 6 Quantitative evaluation for antiseptic property against planktonic bacteria.

Notes: (A) Antibacterial rates of planktonic Gram-positive Staphylococcus aureus for the five specimens in TSB medium; (B) antibacterial rates of planktonic Gram-negative Pseudomonas aeruginosa for the five specimens in TSB medium; (C) antibacterial rates of planktonic Gram-positive S. aureus for the five specimens in TSB + GSH medium; (D) antibacterial rates of planktonic Gram-negative $P$. aeruginosa for the five specimens in TSB + GSH medium. ${ }^{* * P}<0.0$ I, $* * * P<0.00$ I vs glass; ${ }^{*} P<0.05$, $\# P<0.00$ I vs $V 0$; ${ }^{\$ P}<0.05,{ }^{\$ \$} P<0.01,{ }^{\$ \$} \$ P<0.001$ vs $V 3 ;$ \&\&P $<0.01$, \&\&\& $P<0.001$ vs $V 4$. Data expressed as means \pm standard deviation $(n=3)$.

Abbreviations: $\mathrm{V} 0$, homogeneous vanadium metal nanoparticles deposited on quartz glass; $\mathrm{V} 3$, homogeneous $\mathrm{V}_{2} \mathrm{O}_{3}$ nanoparticles deposited on quartz glass; $\mathrm{V} 4$, homogeneous $\mathrm{VO}_{2}$ nanoparticles deposited on quartz glass; $\mathrm{V} 5$, homogeneous $\mathrm{V}_{2} \mathrm{O}_{5}$ nanoparticles deposited on quartz glass; Rap, antibacterial rates of planktonic bacteria; TSB, trypticase soy broth; GSH, glutathione.
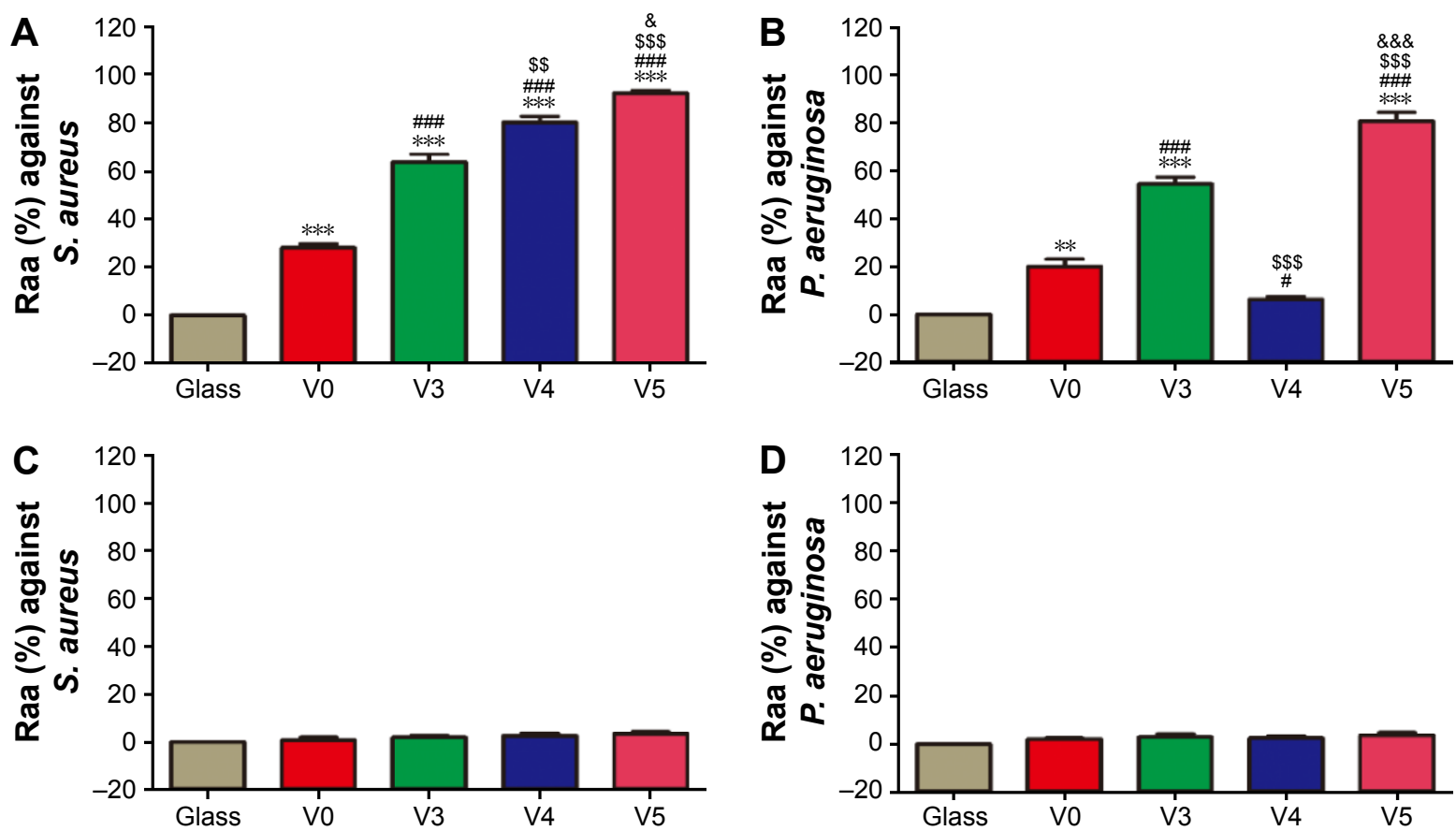

Figure 7 Quantitative evaluation for antiseptic property against sessile bacteria.

Notes: (A) Antimicrobial rates of adherent Gram-positive Staphylococcus aureus for the five samples in TSB medium; (B) antimicrobial rates of adherent Gram-negative Pseudomonas aeruginosa for the five samples in TSB medium; (C) antimicrobial rates of adherent Gram-positive $S$. aureus for the five samples in TSB + GSH medium; (D) antimicrobial rates of adherent Gram-negative $P$. aeruginosa for the five samples in TSB + GSH medium. $* * P<0.0$ I, ****P<0.00I vs glass; $\# P<0.05$, $P$. $P<0.00$ I vs $V 0$; $\$ \$ P<0.01$, ${ }^{\$ \$} \$ P<0.001$ vs $\vee 3 ; \& P<0.05$, \&\&\& $P<0.001$ vs $\vee 4$. Data expressed as means \pm standard deviation $(n=3)$.

Abbreviations: $\mathrm{V} 0$, homogeneous vanadium metal nanoparticles deposited on quartz glass; $\mathrm{V} 3$, homogeneous $\mathrm{V}_{2} \mathrm{O}_{3}$ nanoparticles deposited on quartz glass; $\mathrm{V} 4$, homogeneous $\mathrm{VO}_{2}$ nanoparticles deposited on quartz glass; $\mathrm{V} 5$, homogeneous $\mathrm{V}_{2} \mathrm{O}_{5}$ nanoparticles deposited on quartz glass; Raa, antibacterial rates of adhered bacteria; TSB, trypticase soy broth; GSH, glutathione. 
A
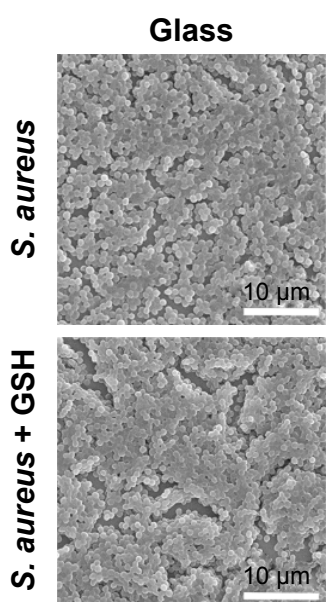

ஸे
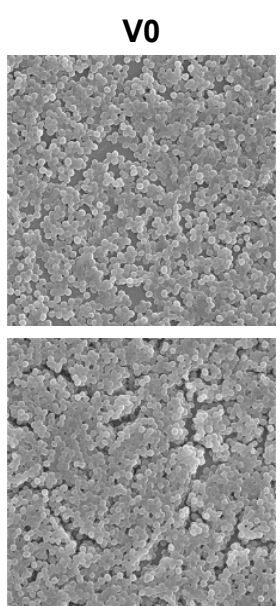

V3
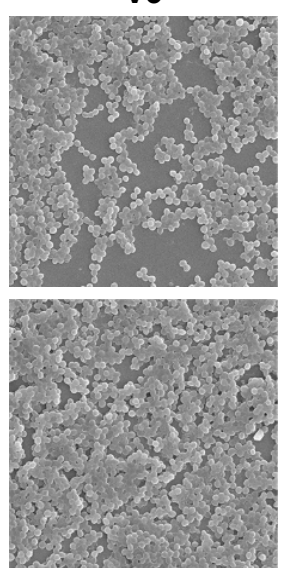

V4
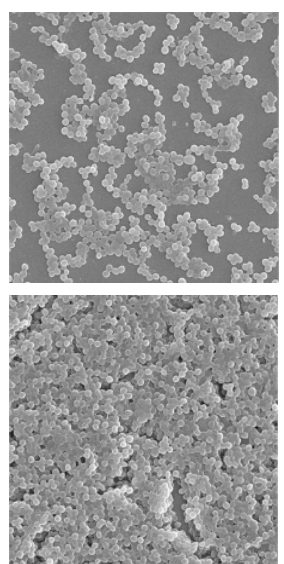

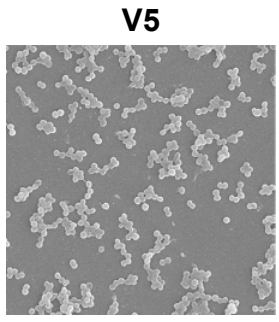

B
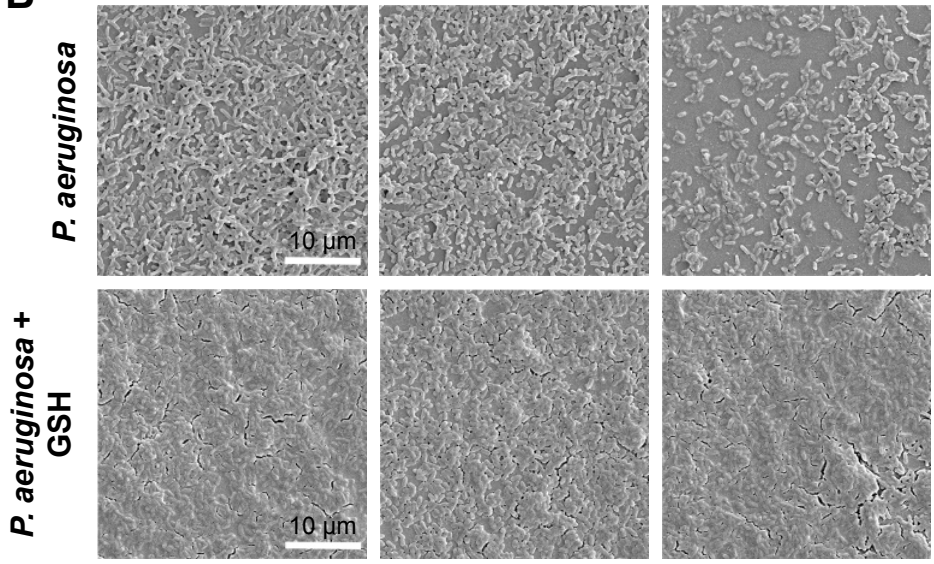
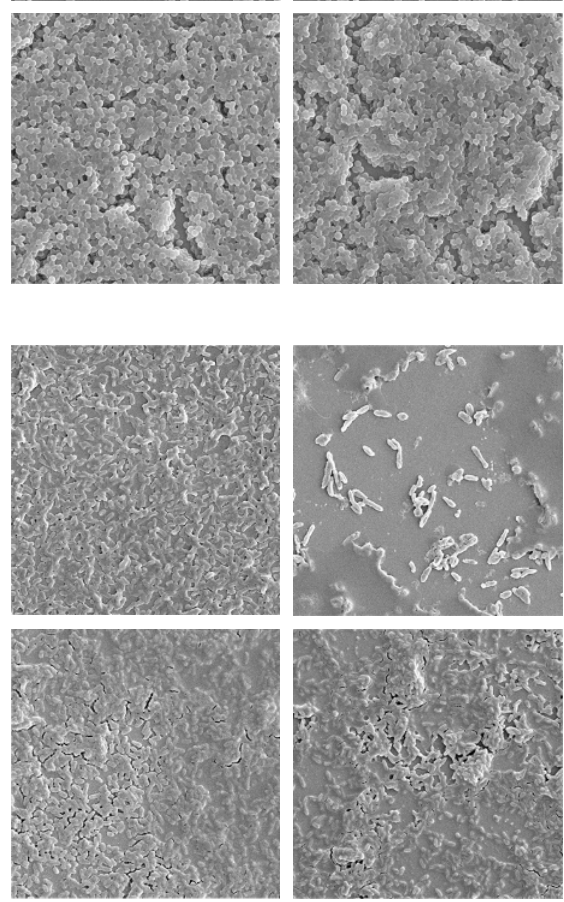

Figure 8 Qualitative assessment of antimicrobial capacity against adherent bacteria by SEM.

Notes: (A) For Gram-positive Staphylococcus aureus, bacterial morphology and biofilm formation on the five samples in TSB (upper) or TSB + GSH (lower) medium; (B) for Gram-negative Pseudomonas aeruginosa, bacterial morphology and biofilm formation on the five samples in TSB (upper) or TSB + GSH (lower) medium. Magnification $\times 2,000$.

Abbreviations: SEM, scanning electron microscopy; $V 0$, homogeneous vanadium metal nanoparticles deposited on quartz glass; $V 3$, homogeneous $\mathrm{V}_{2} \mathrm{O}_{3}$ nanoparticles deposited on quartz glass; $\mathrm{V} 4$, homogeneous $\mathrm{VO}_{2}$ nanoparticles deposited on quartz glass; $\mathrm{V} 5$, homogeneous $\mathrm{V}_{2} \mathrm{O}_{5}$ nanoparticles deposited on quartz glass; TSB, trypticase soy broth; GSH, glutathione.

(Figure 7B and D), especially for V3 and V5. To visualize the bacterial viability and membrane integrity further, live/ dead fluorescence staining was conducted on both adherent bacteria, as shown in Figure 9. For both MRSA (Figure 9A) and $P$. aeruginosa (Figure 9B), fluorescence results were quite consistent with the aforementioned qualitative and quantitative results. Overall, V3, V4, and V5 possessed good antibacterial activity on Gram-positive MRSA, and V3 and V5 had favorable antibacterial ability on Gram-negative $P$. aeruginosa.

\section{Plausible antimicrobial mechanism}

Herein, we tried to understand the possible antibacterial mechanism of the various samples: V0, V3, V4 and V5. For sample, V0 (V-metal nanoparticle film), as evidenced by XPS analysis, natural oxidation occurred on the outermost surface of V-metal nanoparticles $\left(4 \mathrm{~V}+3 \mathrm{O}_{2} \rightarrow 2 \mathrm{~V}_{2} \mathrm{O}_{3}\right)$. The observed antibacterial ability with relatively low efficiency can be attributed to the generation of the $\mathrm{V}_{2} \mathrm{O}_{3}$ phase on the surface. With regard to sample $\mathrm{V} 3\left(\mathrm{~V}_{2} \mathrm{O}_{3}\right.$ nanoparticle film), since $\mathrm{V}_{2} \mathrm{O}_{3}$ is a strong reductant, it may allow electronic charge flowing between $\mathrm{V}_{2} \mathrm{O}_{3}$ nanoparticles and adherent bacteria, ${ }^{36,37}$ which thus disrupts the membrane electron transfer and causes oxidative stress and damage to adherent bacteria. For planktonic bacteria, $\mathrm{V}_{2} \mathrm{O}_{3}$ holds the potential to react gradually with dissolved oxygen in aqueous solution to form $\mathrm{VO}_{2}\left(2 \mathrm{~V}_{2} \mathrm{O}_{3}+\mathrm{O}_{2} \rightarrow 4 \mathrm{VO}_{2}\right)$. The intermediate state of $\mathrm{VO}_{2}$ can gradually oxidize to $\mathrm{V}_{2} \mathrm{O}_{5}\left(4 \mathrm{VO}_{2}+\mathrm{O}_{2} \rightarrow 2 \mathrm{~V}_{2} \mathrm{O}_{5}\right)$, followed by formation of a hydrated surface $\left(\mathrm{V}_{2} \mathrm{O}_{5}+3 \mathrm{H}_{2} \mathrm{O} \rightarrow\right.$ $2 \mathrm{H}_{3} \mathrm{VO}_{4} \cdot{ }^{38} \mathrm{In}$ a slightly alkaline medium (blood), the following reaction occurs: $\mathrm{H}_{3} \mathrm{VO}_{4}+\mathrm{OH}^{-} \rightarrow \mathrm{H}_{2} \mathrm{VO}_{4}^{-}+\mathrm{H}_{2} \mathrm{O} .{ }^{23,39,40}$ The $\mathrm{H}_{2} \mathrm{VO}_{4}^{-}$anions will gradually enter the aqueous solution and account for the observed antiplanktonic bacteria activity. As for sample V4 $\left(\mathrm{VO}_{2}\right.$ nanoparticle film), on one hand, for adherent bacteria, intermediate $\mathrm{VO}_{2}$ exhibited good 
A
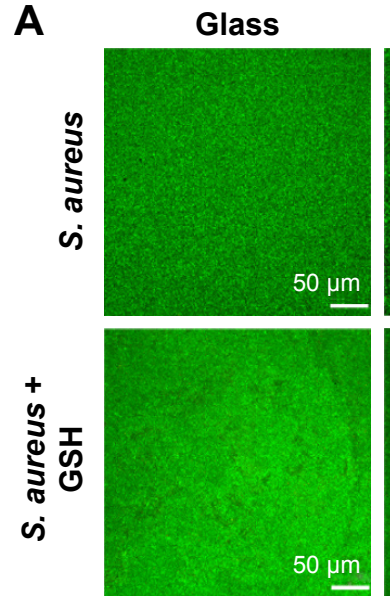

B
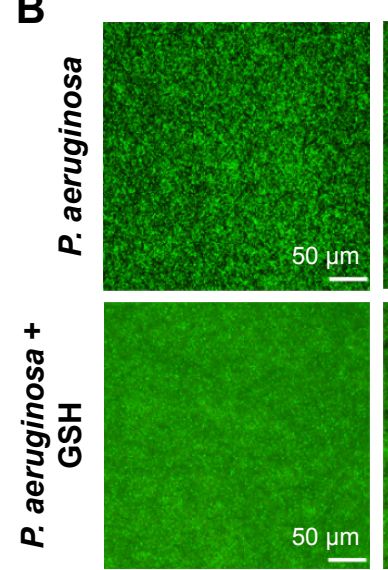

Vo
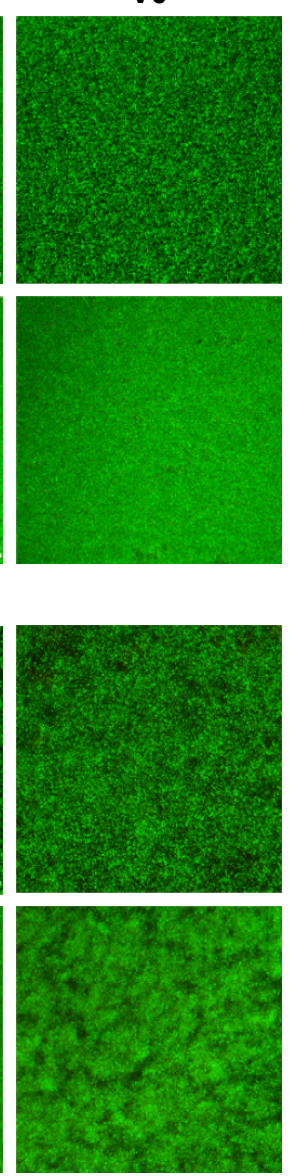

V3
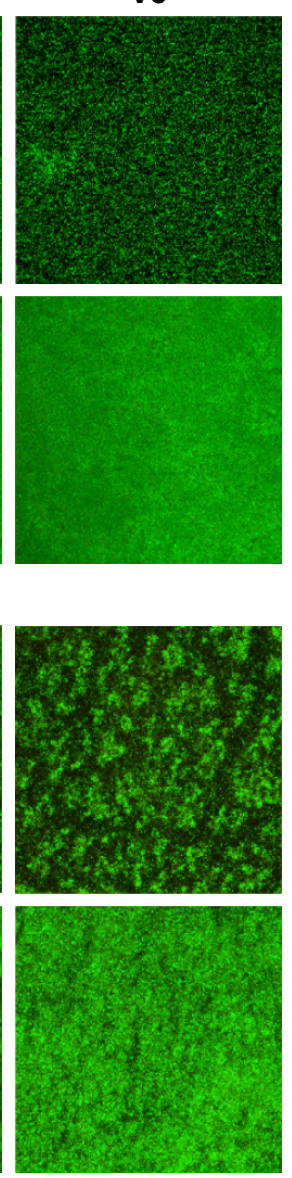

V4
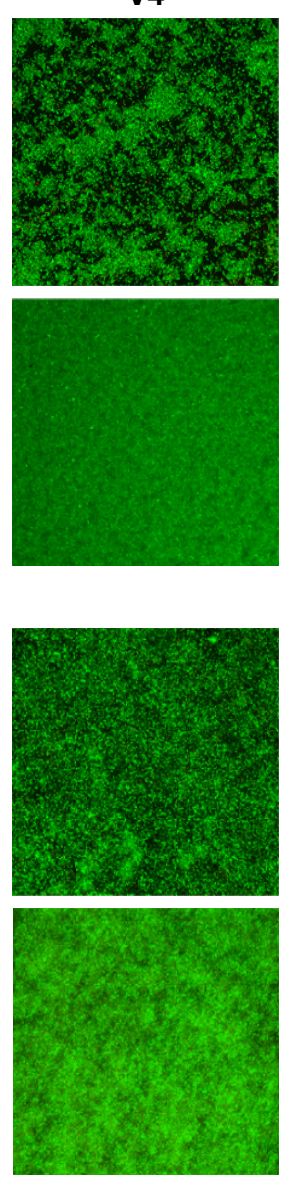

V5
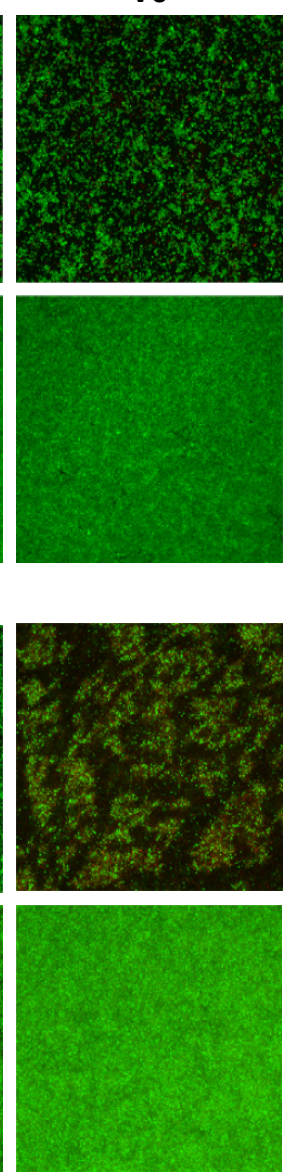

Figure 9 Qualitative assessment of antiseptic property against adherent bacteria by CLSM fluorescence.

Notes: (A) For Gram-positive Staphylococcus aureus, biofilm formation illustrated by live/dead staining results on the five samples in TSB medium with or without GSH antioxidant; (B) for Gram-negative Pseudomonas aeruginosa, biofilm formation illustrated by live/dead staining results on the five samples in TSB medium with or without GSH antioxidant. Magnification $\times 200$.

Abbreviations: CLSM, confocal laser-scanning microscopy; $\vee 0$, homogeneous vanadium metal nanoparticles deposited on quartz glass; $V 3$, homogeneous $\mathrm{V}_{2} \mathrm{O}_{3}$ nanoparticles deposited on quartz glass; $\mathrm{V} 4$, homogeneous $\mathrm{VO}_{2}$ nanoparticles deposited on quartz glass; $\mathrm{V} 5$, homogeneous $\mathrm{V}_{2} \mathrm{O}_{5}$ nanoparticles deposited on quartz glass; TSB, trypticase soy broth; GSH, glutathione.

antibacterial ability on MRSA, while it did not exert this antibacterial effect on $P$. aeruginosa, since it has high tolerance for oxidative stress or ROS level. ${ }^{20}$ On the other hand, for planktonic bacteria, as analyzed herein, the intermediate state $\mathrm{VO}_{2}$ will gradually oxidize $\left(4 \mathrm{VO}_{2}+\mathrm{O}_{2} \rightarrow 2 \mathrm{~V}_{2} \mathrm{O}_{5}\right)$, hydrate $\left(\mathrm{V}_{2} \mathrm{O}_{5}+3 \mathrm{H}_{2} \mathrm{O} \rightarrow 2 \mathrm{H}_{3} \mathrm{VO}_{4}\right)$, and form vanadate anions $\left(\mathrm{H}_{3} \mathrm{VO}_{4}+\mathrm{OH}^{-} \rightarrow \mathrm{H}_{2} \mathrm{VO}_{4}^{-}+\mathrm{H}_{2} \mathrm{O}\right)$ in slightly alkaline media. The formed vanadate ions can be released from the surface and lead to the antibacterial effect on planktonic MRSA, while similarly they had no obvious antibacterial activity on planktonic $P$. aeruginosa.

In regard to sample $\mathrm{V} 5\left(\mathrm{~V}_{2} \mathrm{O}_{5}\right.$ nanoparticle film $), \mathrm{V}_{2} \mathrm{O}_{5}$ is a strong oxidant and may be able to extract electrons from the bacteria membrane and disturb the electron-transport chain, thus causing oxidative damage to adherent bacteria. ${ }^{36,37}$ It has been reported that the redox activity of $\mathrm{V}_{2} \mathrm{O}_{5}$ can be used as a biosensor to detect biological macromolecules in which $\mathrm{V}_{2} \mathrm{O}_{5}$ acts as the charge-exchanging catalyst to complete the oxidation-reduction cycle. ${ }^{41}$ As for the planktonic bacteria, as discussed earlier, the +5 -valence vanadate anions $\left(\mathrm{H}_{2} \mathrm{VO}_{4}^{-}\right)$ can speciate from the surface $\left(\mathrm{V}_{2} \mathrm{O}_{5}+3 \mathrm{H}_{2} \mathrm{O} \rightarrow 2 \mathrm{H}_{3} \mathrm{VO}_{4}\right.$; $\left.\mathrm{H}_{3} \mathrm{VO}_{4}+\mathrm{OH}^{-} \rightarrow \mathrm{H}_{2} \mathrm{VO}_{4}^{-}+\mathrm{H}_{2} \mathrm{O}\right)$ and then enter aqueous solution, finally imposing an antibacterial effect on MRSA and even on $P$. aeruginosa. For the antibacterial difference in samples V5 and V4 against planktonic $P$. aeruginosa, this may have been due to the difference in the availability of $\mathrm{H}_{2} \mathrm{VO}_{4}^{-}$speciating from $\mathrm{V}_{2} \mathrm{O}_{5}$ and $\mathrm{VO}_{2}$ in the slightly alkaline medium. Nevertheless, obviously further work needs to be done to explore this.

Bacteria can carry out respiratory processes to produce power for various life movements. ${ }^{42,43}$ Electrons are provided by low-redox potential donors (eg, NADH, NADPH) and 
then transferred in the membrane electron-transport chain by a series of redox cofactors, finally to terminal electron acceptors, such as $\mathrm{O}_{2}$ molecules. ${ }^{44,45}$ The electron-transfer chain is the main site for intracellular ROS production. ${ }^{46}$ In normal physiological conditions, bacteria can self-regulate to maintain intracellular redox hemostasis through an antioxidant defense system. However, upon exposure to extraneous toxicants, the intracellular redox homeostasis may be disrupted, due to the elevation of the intracellular ROS level caused by the toxicant-induced dysfunction of the membrane electron-transport chain. Here, vanadium exposure holds the high risk of inducing intracellular ROS production elevation in bacteria, because the high redox activity of vanadium species has the potential to interfere with the redox cofactors (eg, $\mathrm{NADP}^{+} / \mathrm{NADPH} \mathrm{FAD}^{2+} / \mathrm{FADH}_{2}, \mathrm{FMN}^{2+} / \mathrm{FMNH}_{2}$ ) in the bacterial electron-transfer chain. ${ }^{17,47}$ As reported, disruption to the membrane electron-transport chain will cause toxicity to bacteria. ${ }^{18,48}$ This is similar to the vanadium-induced toxicity on cellular mitochondria. ${ }^{46,49}$

As discussed earlier, the exposure of bacteria to $\mathrm{V}$ metal, $\mathrm{V}_{2} \mathrm{O}_{3}, \mathrm{VO}_{2}$, and $\mathrm{V}_{2} \mathrm{O}_{5}$ nanofilms may elevate intracellular ROS levels and thus cause oxidative stress and damage. To verify this, we further used DCFH-DA fluorescence dye to visualize intracellular ROS levels, which can be indicated by green fluorescence. As seen in Figure 10, for Gram-positive MRSA, after vanadium exposure, compared with sample glass intracellular ROS levels were sharply elevated in the order of V0, V3, V4, and V5, especially for samples V4 and V5. By comparison, the Gram-negative $P$. aeruginosa were not as sensitive to vanadium exposure as Gram-positive MRSA.
As a result, intracellular ROS levels showed no obvious increase on samples V0, V3, and V4 compared with glass, but sample V5 induced a relatively apparent elevation in intracellular ROS production in P. aeruginosa. Overall, the ROS staining results were quite consistent with these data and analyses. GSH is an important antioxidant for living cells, ${ }^{50}$ and maintains intracellular redox homeostasis by scavenging intracellular ROS. ${ }^{51,52}$ As evidenced here, coincubation of bacteria with GSH antioxidant can apparently alleviate or even eliminate the antibacterial activity of various $\mathrm{VO}_{\mathrm{x}}$ nanoparticle films, further supporting their oxidative stressmediated antibacterial effect.

\section{Erythrocyte-assisting property}

Considering that we intended to use the vanadium-nanoparticle films to resist implant-associated BSI and human erythrocytes do not have mitochondria, we supposed that when coculturing erythrocytes and bacteria on $\mathrm{VO}_{\mathrm{x}}$ nanoparticle films, $\mathrm{VO}_{\mathrm{x}}$ might help erythrocytes fight against bacteria to reduce the risk of hemolysis caused by bacteria exposure. As seen in Figure 11A, without adding bacteria, various samples induced relatively low hemolysis rates (less than $2 \%$ ) in a relatively safe range. By contrast, after Gram-positive MRSA exposure, the glass sample produced a relatively high hemolysis rate of over $60 \%$ (Figure 11B). By comparison, V0, V3, $\mathrm{V} 4$, and V5 produced apparently decreased hemolysis rates of around $20 \%$, especially for sample V5. At the same time, the erythrocytes were also exposed to the Gram-negative $P$. aeruginosa. Corresponding hemolysis rates are given in Figure 11C. From this, it can be seen that only V5 had
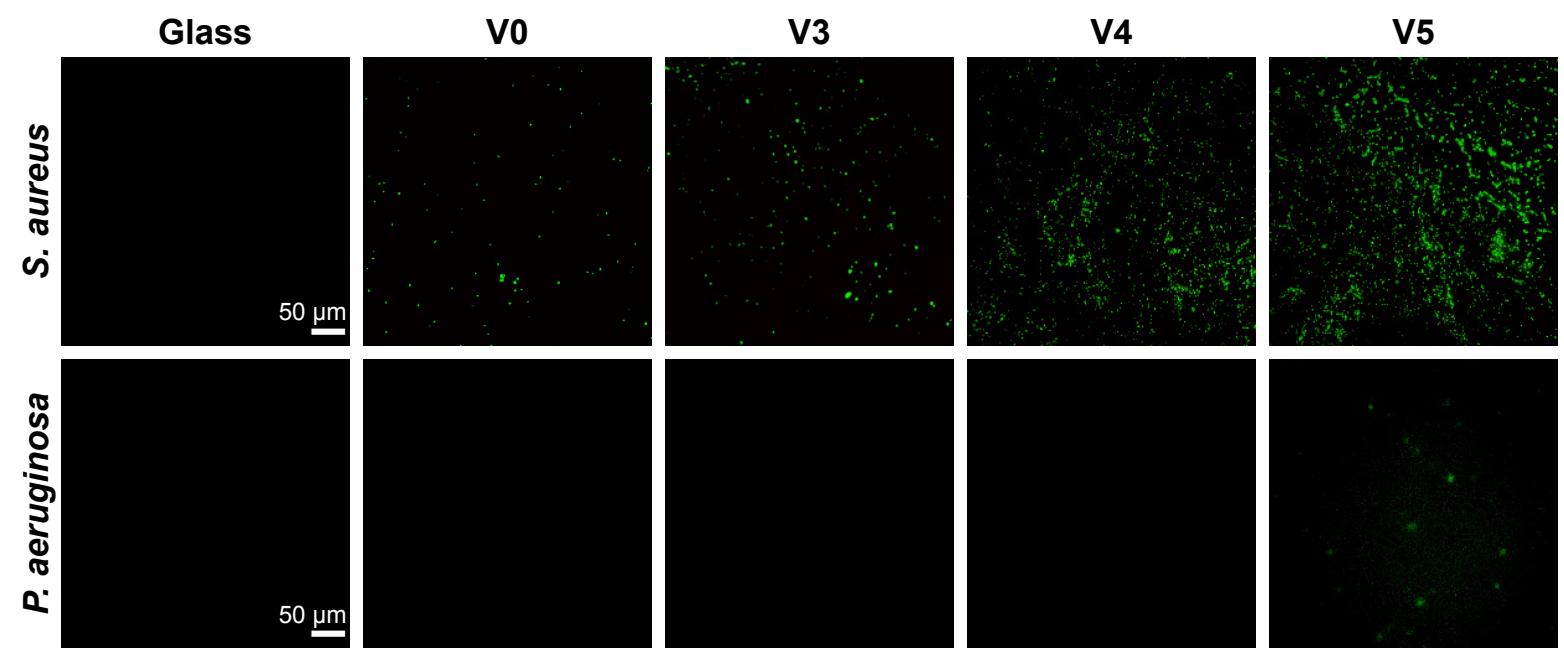

Figure 10 Intracellular ROS levels of Staphylococcus aureus and Pseudomonas aeruginosa on the samples after culturing overnight. Note: Magnification $\times 200$.

Abbreviations: ROS, reactive oxygen species; $\mathrm{V} 0$, homogeneous vanadium metal nanoparticles deposited on quartz glass; $\mathrm{V} 3$, homogeneous $\mathrm{V}_{2} \mathrm{O}_{3}$ nanoparticles deposited on quartz glass; $\mathrm{V} 4$, homogeneous $\mathrm{VO}_{2}$ nanoparticles deposited on quartz glass; $\mathrm{V} 5$, homogeneous $\mathrm{V}_{2} \mathrm{O}_{5}$ nanoparticles deposited on quartz glass. 
A

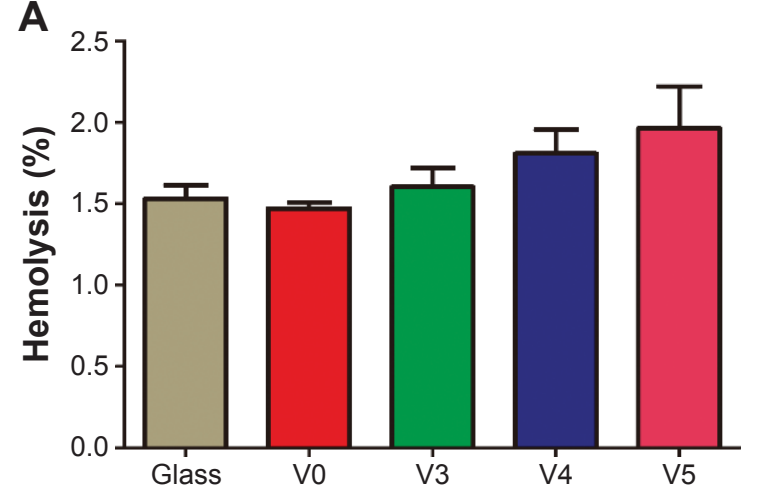

C

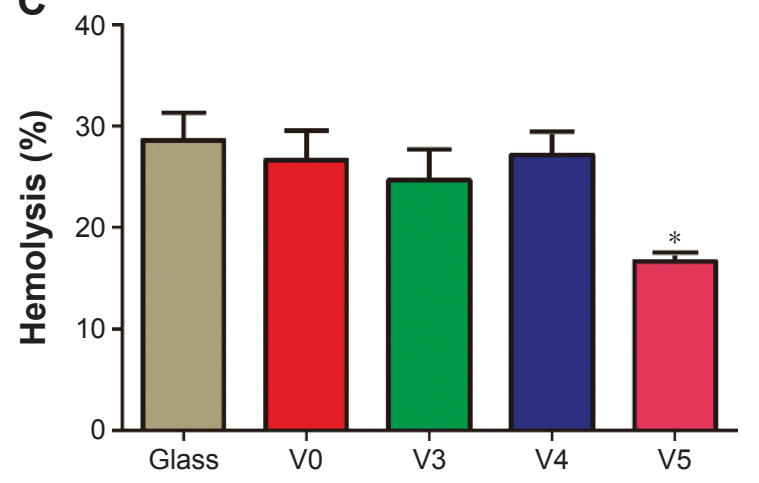

B

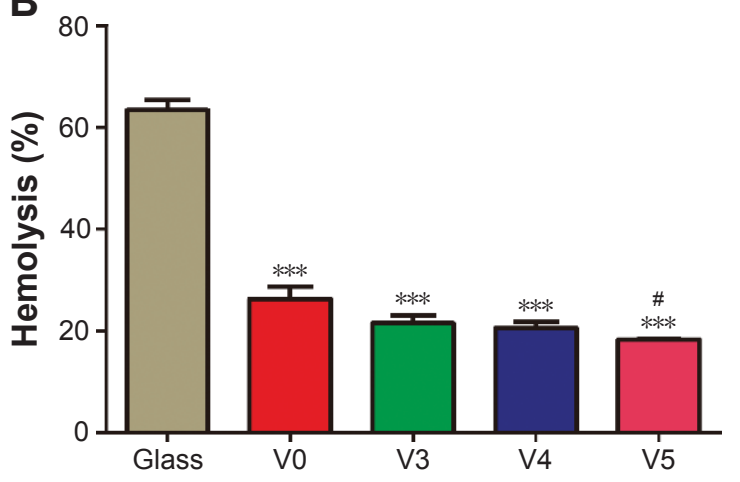

D

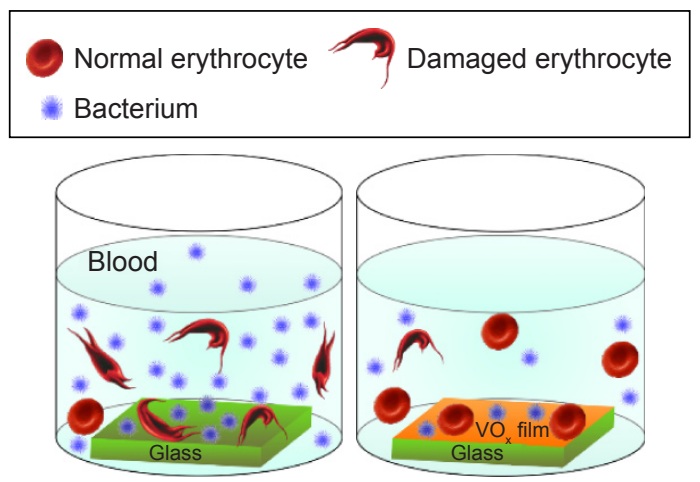

Figure II Hemolysis rate of red blood cells after 24 hours of incubation on the five specimens.

Notes: (A) Erythrocytes were incubated on the five specimens without bacteria; (B) erythrocytes were incubated on the five specimens with Gram-positive Staphylococcus aureus; (C) erythrocytes were incubated on the five specimens with Gram-negative Pseudomonas aeruginosa; (D) interactions of erythrocytes and bacteria upon coexistence in the presence/absence of $V O_{x}$ films. ${ }^{*} P<0.05$, ${ }^{*} * *<<0.001$ vs Glass; ${ }^{*} P<0.05$ vs $V 0$. Data expressed as means \pm standard deviation ( $n=3$ ).

Abbreviations: $\mathrm{V} 0$, homogeneous vanadium metal nanoparticles deposited on quartz glass; $\mathrm{V} 3$, homogeneous $\mathrm{V}_{2} \mathrm{O}_{3}$ nanoparticles deposited on quartz glass; $\mathrm{V} 4$, homogeneous $\mathrm{VO}_{2}$ nanoparticles deposited on quartz glass; $\mathrm{V} 5$, homogeneous $\mathrm{V}_{2} \mathrm{O}_{5}$ nanoparticles deposited on quartz glass; $\mathrm{VO}_{x}$, vanadium of various valences.

an obvious assistance effect on inhibiting bacteria-induced hemolysis. Basically, the obtained results were quite accordant with the antibacterial efficiency of the designed $\mathrm{VO}_{\mathrm{x}}$ nanoparticle films, together demonstrating the erythrocyteassisting but bacteria-combating dual functions. The whole interaction process is illustrated in Figure 11D.

Vanadium compounds end up in the human bloodstream. ${ }^{53}$ The major transporter for both vanadate anions $\left(\mathrm{H}_{2} \mathrm{VO}_{4}^{-}\right)$and vanadyl cations $\left(\mathrm{VO}^{2+}\right)$ is transferrin. In addition, $\mathrm{H}_{2} \mathrm{VO}_{4}^{-}$is easily soluble and also exists as a free anion in blood (ie, unbound to transferrin). ${ }^{54}$ From the bloodstream, vanadium will be distributed to body tissues and bones. Actually, vanadium is presumably one of the essential trace elements in the human body. ${ }^{22}$ Bones can serve as a storage pool for vanadate. Vanadium holds the potential to promote soft tissue-implant integration ${ }^{55}$ and participate in the bone-mineralization process ${ }^{56}$ These can control the potential toxicity of vanadium on normal cells if delivered in an appropriate dosage for safety. In addition, bacteria in the human bloodstream require free iron to produce lipopolysaccharide endotoxins and cause inflammation. ${ }^{57}$ The inhibition of hemolysis can prevent bacteria from acquiring iron from erythrocytes in bloodstream. Basically, the designed $\mathrm{VO}_{\mathrm{x}}$ nanoparticle films can exert favorable anti-infection function that assists erythrocytes to combat bacteria in the human bloodstream, which from the perspective of surface modification and functionalization may contribute to the BSI prophylaxis of biomedical devices, such as implants, stents, and catheters.

\section{Conclusion}

In the present study, we firstly deposited $\mathrm{V}$ metal, $\mathrm{V}_{2} \mathrm{O}_{3}, \mathrm{VO}_{2}$ and $\mathrm{V}_{2} \mathrm{O}_{5}$ nanofilms on quartz glass by magnetron sputtering. These nano- $\mathrm{VO}_{\mathrm{x}}$ films were homogeneous and released vanadium ions in a continuous fashion. It was found that lowvalence $\mathrm{VO}_{x}$ films had better cytocompatibility. Furthermore, these $\mathrm{VO}_{\mathrm{x}}$ nanofilms possessed excellent antibacterial ability against MRSA and P. aeruginosa, especially for MRSA, and this antibacterial effect increased with higher vanadium chemical valence. Moreover, the $\mathrm{VO}_{\mathrm{x}}$ films effectively inhibited the hemolysis of human erythrocytes caused by 
bacteria in a novel coculture model. As a result, they imposed favorable anti-infection effects that assisted erythrocytes to combat bacteria in the human bloodstream. We hope this work can provide new insights for biomedical applications of inorganic vanadium compounds and attract growing interest in this area. From the viewpoint of surface modification, this work may be conducive to the prophylaxis of BSI related to biomedical devices, such as catheters and stents.

\section{Acknowledgments}

This work was jointly supported by the National Natural Science Foundation of China (grants 81271962, 81472109, 81472108 , and 81301571), the high-tech project of MOST (2014AA032802), and the Science and Technology Commission of Shanghai Municipality (STCSM; 14DZ2261203).

\section{Disclosure}

The authors report no conflicts of interest in this work.

\section{References}

1. Casey AL, Mermel LA, Nightingale P, Elliott TS. Antimicrobial central venous catheters in adults: a systematic review and meta-analysis. Lancet Infect Dis. 2008;8(12):763-776.

2. Sendi P, Banderet F, Graber P, Zimmerli W. Periprosthetic joint infection following Staphylococcus aureus bacteremia. J Infect. 2011; 63(1):17-22.

3. Boucher HW. Challenges in anti-infective development in the era of bad bugs, no drugs: a regulatory perspective using the example of bloodstream infection as an indication. Clin Infect Dis. 2010;50 Suppl 1: S4-S9.

4. Viola GM, Rosenblatt J, Raad II. Drug eluting antimicrobial vascular catheters: progress and promise. Adv Drug Deliv Rev. Epub 2016 Aug 2.

5. Cass AL, Kelly JW, Probst JC, Addy CL, McKeown RE. Identification of device-associated infections utilizing administrative data. Am J Infect Control. 2013;41(12):1195-1199.

6. Laupland KB, Lyytikäinen O, Søgaard M, et al. The changing epidemiology of Staphylococcus aureus bloodstream infection: a multinational population-based surveillance study. Clin Microbiol Infect. 2013; 19(5):465-471.

7. Lim CJ, Cheng AC, Kong DC, Peleg AY. Community-onset bloodstream infection with multidrug-resistant organisms: a matched case-control study. BMC Infect Dis. 2014;14:126.

8. Micek ST, Lloyd AE, Ritchie DJ, Reichley RM, Fraser VJ, Kollef MH. Pseudomonas aeruginosa bloodstream infection: importance of appropriate initial antimicrobial treatment. Antimicrob Agents Chemother. 2005; 49(4):1306-1311.

9. Donlan RM. Biofilm elimination on intravascular catheters: important considerations for the infectious disease practitioner. Clin Infect Dis. 2011;52(8):1038-1045.

10. Wu K, Yang Y, Zhang Y, Deng J, Lin C. Antimicrobial activity and cytocompatibility of silver nanoparticles coated catheters via a biomimetic surface functionalization strategy. Int J Nanomedicine. 2015;10: 7241-7252.

11. Vallés J, Rello J, Ochagavía A, Garnacho J, Alcalá MA. Communityacquired bloodstream infection in critically ill adult patients: impact of shock and inappropriate antibiotic therapy on survival. Chest. 2003; 123(5):1615-1624.

12. Zazo H, Colino CI, Lanao JM. Current applications of nanoparticles in infectious diseases. J Control Release. 2016;224:86-102.
13. Huh AJ, Kwon YJ. "Nanoantibiotics": a new paradigm for treating infectious diseases using nanomaterials in the antibiotics resistant era. $J$ Control Release. 2011;156(2):128-145.

14. Taylor E, Webster TJ. Reducing infections through nanotechnology and nanoparticles. Int J Nanomedicine. 2011;6:1463-1473.

15. Soares SS, Martins H, Duarte RO, et al. Vanadium distribution, lipid peroxidation and oxidative stress markers upon decavanadate in vivo administration. J Inorg Biochem. 2007;101(1):80-88.

16. Soares SS, Gutiérrez-Merino C, Aureliano M. Mitochondria as a target for decavanadate toxicity in Sparus aurata heart. Aquat Toxicol. 2007;83(1):1-9.

17. Aureliano M. Decavanadate: a journey in a search of a role. Dalton Trans. 2009;(42):9093-9100.

18. Li J, Wang G, Zhu H, et al. Antibacterial activity of large-area monolayer graphene film manipulated by charge transfer. Sci Rep. 2014; 4:4359.

19. Maia PI, Pavan FR, Leite CQ, et al. Vanadium complexes with thiosemicarbazones: synthesis, characterization, crystal structures and anti-Mycobacterium tuberculosis activity. Polyhedron. 2009;28(2): 398-406.

20. Li J, Zhou H, Wang J, et al. Oxidative stress-mediated selective antimicrobial ability of nano- $\mathrm{VO}_{2}$ against Gram-positive bacteria for environmental and biomedical applications. Nanoscale. 2016;8(23): 11907-11923.

21. Gajera SB, Mehta JV, Patel MN. Metal-based biologically active compounds: design, synthesis, medicinal, toxicity and DNA interaction assay. Med Chem Res. 2016;25(3):526-537.

22. Michibata H. Vanadium: Biochemical and Molecular Biological Approaches. Heidelberg: Springer; 2011.

23. Crans DC, Smee JJ, Gaidamauskas E, Yang L. The chemistry and biochemistry of vanadium and the biological activities exerted by vanadium compounds. Chem Rev. 2004;104(2):849-902.

24. Chadwick W, Maudsley S. The devil is in the dose: complexity of receptor systems and responses. In: Mattson MP, Calabrese EJ, editors. Hormesis: A Revolution in Biology, Toxicology and Medicine. Heidelberg: Springer; 2010:95-108.

25. Gresser M, Tracey A. Vanadates as phosphate analogs in biochemistry. In: Chasteen ND, editor. Vanadium in Biological Systems: Physiology and Biochemistry. Dordrecht, Netherlands: Kluwer; 1990:63-79.

26. Zhang Y, Yang XD, Wang K, Crans DC. The permeability and cytotoxicity of insulin-mimetic vanadium (III, IV, V)-dipicolinate complexes. J Inorg Biochem. 2006;100(1):80-87.

27. Capella LS, Gefé MR, Silva EF, et al. Mechanisms of vanadate-induced cellular toxicity: role of cellular glutathione and NADPH. Arch Biochem Biophys. 2002;406(1):65-72.

28. Wang R, Braughton KR, Kretschmer D, et al. Identification of novel cytolytic peptides as key virulence determinants for communityassociated MRSA. Nat Med. 2007;13(12):1510-1514.

29. Soong G, Chun J, Parker D, Prince A. Staphylococcus aureus activation of caspase 1/calpain signaling mediates invasion through human keratinocytes. J Infect Dis. 2012;205(10):1571-1579.

30. Esteban MA, Wang T, Qin B, et al. Vitamin C enhances the generation of mouse and human induced pluripotent stem cells. Cell Stem Cell. 2010;6(1):71-79.

31. Kasperkiewicz J, Kovacich JA, Lichtman D. XPS studies of vanadium and vanadium oxides. JElectron Spectros Relat Phenomena. 1983;32(2): $123-132$.

32. Colton RJ, Guzman AM, Rabalais JW. Electrochromism in some thinfilm transition-metal oxides characterized by X-ray electron spectroscopy. J Appl Phys. 1978;49(1):409-416.

33. Zhou H, Li J, Xin Y, Cao X, Bao S, Jin P. Electron transfer induced thermochromism in a $\mathrm{VO}_{2}$-graphene-Ge heterostructure. J Mater Chem C Mater Opt Electron Devices. 2015;3(19):5089-5097.

34. Berry FJ, Brett ME, Marbrow RA, Patterson WR. Notes. An X-ray photoelectron spectroscopic study of the surface properties of vanadium antimonate and $\beta$-antimony tetroxide. Dalton Trans. 1984(5): 985-987. 
35. Wang J, Li J, Qian S, et al. Antibacterial surface design of titaniumbased biomaterials for enhanced bacteria-killing and cell-assisting functions against periprosthetic joint infection. ACS Appl Mater Interfaces. 2016;8(17):11162-11178

36. Zhang H, Ji Z, Xia T, et al. Use of metal oxide nanoparticle band gap to develop a predictive paradigm for oxidative stress and acute pulmonary inflammation. ACS Nano. 2012;6(5):4349-4368.

37. Kaweeteerawat C, Ivask A, Liu R, et al. Toxicity of metal oxide nanoparticles in Escherichia coli correlates with conduction band and hydration energies. Environ Sci Technol. 2015;49(2):1105-1112.

38. Parks GA. The isoelectric points of solid oxides, solid hydroxides, and aqueous hydroxo complex systems. Chem Rev. 1965;65(2):177-198.

39. Chasteen ND. The biochemistry of vanadium. In: Copper, Molybdenum, and Vanadium in Biological Systems. Vol 53. Heidelberg: Springer; 1983: 105-138.

40. Zhou H, Li J, Bao S, Wang D, Liu X, Jin P. The potential cytotoxicity and mechanism of $\mathrm{VO}_{2}$ thin films for intelligent thermochromic windows. RSC Adv. 2015;5(129):106315-106324.

41. Bezerra AG, Barison A, Oliveira VS, et al. The mechanism of cysteine detection in biological media by means of vanadium oxide nanoparticles. J Nanopart Res. 2012;14(9):1123.

42. Reece SY, Nocera DG. Proton-coupled electron transfer in biology: results from synergistic studies in natural and model systems. Annu Rev Biochem. 2009;78:673-699.

43. Myers C, Nealson KH. Bacterial manganese reduction and growth with manganese oxide as the sole electron acceptor. Science. 1988; 240(4857):1319-1321.

44. Harris HW, El-Naggar MY, Bretschger O, et al. Electrokinesis is a microbial behavior that requires extracellular electron transport. Proc Natl Acad Sci U S A. 2010;107(1):326-331.

45. Hartshorne RS, Reardon CL, Ross D, et al. Characterization of an electron conduit between bacteria and the extracellular environment. Proc Natl Acad Sci US A. 2009;106(52):22169-22174.
46. Hosseini MJ, Shaki F, Ghazi-Khansari M, Pourahmad J. Toxicity of vanadium on isolated rat liver mitochondria: a new mechanistic approach. Metallomics. 2013;5(2):152-166.

47. Ghosh SK, Saha R, Saha B. Toxicity of inorganic vanadium compounds. Res Chem Intermed. 2014;41(7):4873-4897.

48. Pang M, Hu J, Zeng HC. Synthesis, morphological control, and antibacterial properties of hollow/solid $\mathrm{Ag}_{2} \mathrm{~S} / \mathrm{Ag}$ heterodimers. J Am Chem Soc. 2010;132(31):10771-10785.

49. Zhao Y, Ye L, Liu H, et al. Vanadium compounds induced mitochondria permeability transition pore (PTP) opening related to oxidative stress. J Inorg Biochem. 2010;104(4):371-378.

50. Fahey RC, Brown WC, Adams WB, Worsham MB. Occurrence of glutathione in bacteria. J Bacteriol. 1978;133(3):1126-1129.

51. Winterbourn CC, Metodiewa D. Reactivity of biologically important thiol compounds with superoxide and hydrogen peroxide. Free Radic Biol Med. 1999;27(3-4):322-328.

52. Carmel-Harel O, Storz G. Roles of the glutathione- and thioredoxindependent reduction systems in the Escherichia coli and Saccharomyces cerevisiae responses to oxidative stress. Annu Rev Microbiol. 2000;54: 439-461.

53. Gorzsás A, Andersson I, Pettersson L. On the fate of vanadate in human blood. Eur J Inorg Chem. 2006;2006(18):3559-3565.

54. Rehder D. Implications of vanadium in technical applications and pharmaceutical issues. Inorg Chim Acta. 2017;455(2):378-389.

55. Jarrell JD, Dolly B, Morgan JR. Controlled release of vanadium from titanium oxide coatings for improved integration of soft tissue implants. J Biomed Mater Res A. 2009;90(1):272-281.

56. Barrio DA, Etcheverry SB. Potential use of vanadium compounds in therapeutics. Curr Med Chem. 2010;17(31):3632-3642.

57. Kell DB, Pretorius E. On the translocation of bacteria and their lipopolysaccharides between blood and peripheral locations in chronic, inflammatory diseases: the central roles of LPS and LPS-induced cell death. Integr Biol (Camb). 2015;7(11):1339-1377.
International Journal of Nanomedicine

\section{Publish your work in this journal}

The International Journal of Nanomedicine is an international, peerreviewed journal focusing on the application of nanotechnology in diagnostics, therapeutics, and drug delivery systems throughout the biomedical field. This journal is indexed on PubMed Central, MedLine, CAS, SciSearch $®$, Current Contents ${ }^{\circledR} /$ Clinical Medicine,

\section{Dovepress}

Journal Citation Reports/Science Edition, EMBase, Scopus and the Elsevier Bibliographic databases. The manuscript management system is completely online and includes a very quick and fair peer-review system, which is all easy to use. Visit http://www.dovepress.com/ testimonials.php to read real quotes from published authors. 